\title{
Kisspeptin Depolarizes Gonadotropin-Releasing Hormone Neurons through Activation of TRPC-Like Cationic Channels
}

\author{
Chunguang Zhang, ${ }^{1}$ Troy A. Roepke, ${ }^{1}$ Martin J. Kelly, ${ }^{1}$ and Oline K. Rønnekleiv ${ }^{1,2,3}$ \\ Departments of ${ }^{1}$ Physiology and Pharmacology and ${ }^{2}$ Anesthesiology and Perioperative Medicine, and ${ }^{3}$ Division of Neuroscience, Oregon National Primate \\ Research Center, Oregon Health \& Science University, Portland, Oregon 97239-3089
}

\begin{abstract}
Kisspeptin and its cognate receptor, GPR54, are critical for reproductive development and for the regulation of gonadotropin-releasing hormone (GnRH) secretion. Although kisspeptin has been found to depolarize GnRH neurons, the underlying ionic mechanism has not been elucidated. Presently, we found that kisspeptin depolarized GnRH neurons in a concentration-dependent manner with a maximum depolarization of $22.6 \pm 0.6 \mathrm{mV}$ and $\mathrm{EC}_{50}$ of $2.8 \pm 0.2 \mathrm{~nm}$. Under voltage-clamp conditions, kisspeptin induced an inward current of $18.2 \pm 1.6 \mathrm{pA}\left(V_{\text {hold }}=-60 \mathrm{mV}\right)$ that reversed near $-115 \mathrm{mV}$ in $\mathrm{GnRH}$ neurons. The more negative reversal potential than $E_{\mathrm{K}}{ }^{+}(-90$ $\mathrm{mV}$ ) was caused by the concurrent inhibition of barium-sensitive, inwardly rectifying (Kir) potassium channels and activation of sodiumdependent, nonselective cationic channels (NSCCs). Indeed, reducing extracellular $\mathrm{Na}^{+}$(to $5 \mathrm{~mm}$ ) essentially eliminated the kisspeptininduced inward current. The current-voltage relationships of the kisspeptin-activated NSCC currents exhibited double rectification with negative slope conductance below $-40 \mathrm{mV}$ in the majority of the cells. Pharmacological examination showed that the kisspeptin-induced inward currents were blocked by TRPC (canonical transient receptor potential) channel blockers 2-APB (2-aminoethyl diphenylborinate), flufenamic acid, SKF96365 (1-[ $\beta$-[3-(4-methoxyphenyl)propoxy]-4-methoxyphenethyl]-1 $H$-imidazole hydrochloride), and $\mathrm{Cd}^{2+}$, but not by lanthanum $(100 \mu \mathrm{m})$. Furthermore, single-cell reverse transcription-PCR analysis revealed that TRPC1, TRPC3, TRPC4, TRPC5, TRPC6, and TRPC7 subunits were expressed in GnRH neurons. Therefore, it appears that kisspeptin depolarizes GnRH neurons through activating TRPC-like channels and, to a lesser extent, inhibition of Kir channels. These actions of kisspeptin contribute to the pronounced excitation of $\mathrm{GnRH}$ neurons that is critical for mammalian reproduction.
\end{abstract}

Key words: nonselective cationic channels; Kir channels; GPR54; phospholipase C; diacylglycerol; single-cell RT-PCR

\section{Introduction}

Kisspeptins, encoded by the Kiss-1 gene, are currently recognized as key factors in the regulation of reproductive development and functions (Gottsch et al., 2006; Kuohung and Kaiser, 2006; Plant, 2006; Tena-Sempere, 2006). The Kiss-1 gene encodes a 145 aa protein, which is proteolytically processed to produce a 54 aa peptide called kisspeptin-54 and several other smaller peptide fragments (Kotani et al., 2001). Kisspeptin-54 has been identified as the endogenous ligand of an orphan G-protein-coupled receptor, GPR54 (Kotani et al., 2001; Stafford et al., 2002). In addition to kisspeptin-54, the smaller peptide fragments derived from the precursor protein (e.g., kisspeptin 14, 13, and 10) all have biological activity at the GPR54 receptor (Kotani et al., 2001; Ohtaki et al., 2001). GPR54 is expressed both in the pituitary and in gonadotropin-releasing hormone $(\mathrm{GnRH})$ neurons (Kotani et al., 2001; Irwig et al., 2004; Han et al., 2005; Messager et al., 2005).

Received Dec. 3, 2007; revised March 17, 2008; accepted March 19, 2008.

This work was supported by Public Health Service Grants NS 38809, NS 43330, and DK 68098. We thank Dr. Suzanne Moenter (University of Virginia, Charlottesville, VA) for providing the transgenic EGFP-GnRH mice and Martha A. Bosch and Elizabeth Rick for their excellent technical assistance.

Correspondence should be addressed to either Dr. Martin J. Kelly or Dr. Oline K. Rønnekleiv, Department of Physiology and Pharmacology, L334, Oregon Health \& Science University, 3181 Southwest Sam Jackson Park Road, Portland, 0R 97239-2098. E-mail: kellym@ohsu.edu or ronnekle@ohsu.edu.

DOI:10.1523/JNEUROSCI.5352-07.2008

Copyright $\odot 2008$ Society for Neuroscience $\quad$ 0270-6474/08/284423-12\$15.00/0
However, evidence suggests that the stimulation of gonadotropin secretion by kisspeptin is by direct activation of $\mathrm{GnRH}$ neurons and not pituitary gonadotropes (Gottsch et al., 2006; Kauffman et al., 2007b). Mutations in GPR54 cause autosomal recessive idiopathic hypogonadotropic hypogonadism in humans (De Roux et al., 2003; Seminara et al., 2003), whereas deletion of GPR54 in mice causes defective sexual development and reproductive failure (Seminara et al., 2003). In addition, targeted deletion of the Kiss- 1 gene in mice causes the same phenotype as mutation of the GPR54 gene (d'Anglemont de Tassigny et al., 2007), suggesting, as reported previously based on binding assays, that kisspeptins are the endogenous ligands for the GPR54 receptor (Kotani et al., 2001). Collectively, these findings suggest that kisspeptins and their GPR54 receptor are essential for normal reproductive physiology.

Recently, there have been multiple studies on the regulation of kisspeptin gene expression and the role of kisspeptins in regulating GnRH and luteinizing hormone secretion (Gottsch et al., 2004; Irwig et al., 2004; Navarro et al., 2004; Castellano et al., 2005; Messager et al., 2005; Roa et al., 2006; Smith et al., 2006). Kisspeptin neurons are located in the arcuate nucleus and the preoptic area (POA) and are differentially regulated by estrogen (Smith et al., 2006). Centrally administered kisspeptins stimulate $\mathrm{GnRH}$ and gonadotropin secretion in prepubertal and adult animals presumably by an action in GnRH neurons (Gottsch et al., 
2004; Irwig et al., 2004; Messager et al., 2005). Kisspeptin, when applied to GnRH neurons in vitro, potently activates these neurons and causes increased neuronal firing (Han et al., 2005; Quaynor et al., 2007; Pielecka-Fortuna et al., 2008). In Chinese hamster ovary K1 cells that express GPR54 receptors, kisspeptins cause increased phosphatidylinositol 4,5-bisphosphate $\left(\mathrm{PIP}_{2}\right)$ hydrolysis, calcium mobilization, and mitogen-activated protein (MAP) kinase phosphorylation (Kotani et al., 2001). Moreover, these signaling pathways appear to be necessary for kisspeptin10 -stimulated GnRH secretion in rat hypothalamic explants (Castellano et al., 2006). However, the ionic mechanism(s) by which kisspeptin depolarizes GnRH neurons is (are) essentially unknown.

Therefore, in this study, we investigated the depolarizing effects of kisspeptin and the underlying ionic mechanisms in $\mathrm{GnRH}$ neurons. We found that kisspeptin depolarized $\mathrm{GnRH}$ neurons mainly through activation of a canonical transient receptor potential (TRPC)-like cationic channel. We also found that most of the TRPC channels are expressed in subpopulations of GnRH neurons.

\section{Materials and Methods}

Animals and treatments. All animal treatments described in this study are in accordance with institutional guidelines based on National Institutes of Health standards, and were performed with Institutional Animal Care and Use Committee approval at the Oregon Health \& Science University. Transgenic female mice expressing enhanced green fluorescent protein (EGFP) under the control of the GnRH promoter (EGFP-GnRH) were used in these studies (Suter et al., 2000). Animals were group-housed until surgery after which time they were housed individually. All animals were maintained under controlled temperature and photoperiod (lights on at 6:00 A.M. and off at 6:00 P.M.) and given ad libitum access to food and water.

Our initial experiments showed that, in the presence of tetrodotoxin (TTX), the kisspeptin (100 nM)-induced depolarization was not significantly different $(24.3 \pm 3.3$ vs $21.6 \pm 3.1 \mathrm{mV} ; p>0.05 ; n=6)$ in neurons from mice with low uterine weight $(48 \pm 8 \mathrm{mg}$ ) compared with that from mice with high uterine weight $(135 \pm 8 \mathrm{mg})$, respectively, which indicates that the kisspeptin-induced depolarization may not be modulated by estrogen. A recent report confirms our findings that estrogen does not appear to affect the postsynaptic response to kisspeptin (PieleckaFortuna et al., 2008). However, in the remainder of the experiments we used ovariectomized (ovx), oil-treated adult female GnRH mice to ensure that variation in circulating estrogen did not influence our results.

Animals were ovx under ketamine/xylazine ( 1 and $0.1 \mathrm{mg} / 10 \mathrm{~g}$, respectively) anesthesia and implanted with an oil capsule for 4-7 d. On the day of an experiment, the animals were killed at 10:00-11:00 A.M., at which time the uterus was removed and weighed. For these ovx and oil capsuleimplanted female mice, their mean uterine weight was $30.3 \pm 0.7 \mathrm{mg}$ $(n=53)$. The uterine weight was used as an indicator of circulating E2 levels as reported previously (Bronson and Vom, 1979; Gee et al., 1984). In addition, intact adult female mice were used for the single-cell reverse transcription-PCR (scRT-PCR) determination. The animals were killed at 10:00 A.M., and the uterus was removed and weighed.

Preparation of POA-GnRH slices. Mice were killed by decapitation. The brain was rapidly removed from the skull and a block containing the diagonal band-POA (DB-POA) was immediately dissected. The DBPOA block was submerged in cold $\left(4^{\circ} \mathrm{C}\right)$ oxygenated $\left(95 \% \mathrm{O}_{2}, 5 \% \mathrm{CO}_{2}\right)$ high-sucrose CSF (in mM: 208 sucrose, $2 \mathrm{KCl}, 26 \mathrm{NaHCO}_{3}, 10$ glucose, $1.25 \mathrm{NaH}_{2} \mathrm{PO}_{4}, 2 \mathrm{MgSO}_{4}, 1 \mathrm{MgCl}_{2}, 10$ HEPES, $\mathrm{pH}$ 7.4). Coronal slices $(200 \mu \mathrm{m})$ from the DB-POA were cut on a vibratome during which time $(10 \mathrm{~min})$ the slices were bathed in high-sucrose CSF at $4^{\circ} \mathrm{C}$. The slices were then transferred to an auxiliary chamber in which they were kept at room temperature $\left(25^{\circ} \mathrm{C}\right)$ in artificial CSF (aCSF) consisting of the following (in mM): $124 \mathrm{NaCl}, 5 \mathrm{KCl}, 2.6 \mathrm{NaH}_{2} \mathrm{PO}_{4}, 2 \mathrm{MgSO}_{4}, 2 \mathrm{CaCl}_{2}, 26$ $\mathrm{NaHCO}_{3}, 10$ HEPES, 10 glucose, $\mathrm{pH} 7.4$, until recording (recovery for $2 \mathrm{~h}$ ). A single slice was transferred to the recording chamber at a time, and was kept viable by continually perfusing with warm $\left(35^{\circ} \mathrm{C}\right)$, oxygenated aCSF at $1.5 \mathrm{ml} / \mathrm{min}$.

Visualized whole-cell patch recording using epifluorescence and infrareddifferential interference contrast videomicroscopy. Whole-cell patch recordings were made under a Carl Zeiss (Jena, Germany) Axioskop FS outfitted with epifluorescence (FITC filter set) and infrared-differential interference contrast video microscopy. The EGFP-tagged GnRH neurons in a slice were visualized through a $40 \times$ water-immersion objective (Achroplan; Carl Zeiss). Patch pipettes (A-M Systems, Carlsborg, WA; $1.5 \mathrm{~mm}$ outer diameter borosilicate glass) were pulled on a Brown/Flaming puller (Sutter Instruments, Novato, CA; model P-97). Pipette resistances were 4-6 M $\Omega$ when filled with pipette solutions. In whole-cell configuration, access resistance was 10-20 M . Current-clamp and voltage-clamp experiments were performed with an Axopatch 1D amplifier (Molecular Devices, Sunnyvale, CA). Electrophysiological signals were digitized with Digidata 1322A (Molecular Devices). Kisspeptininduced currents were measured at a holding potential of $-60 \mathrm{mV}$. Steady-state $I-V$ plots were generally constructed with step command potentials from -50 to $-120 \mathrm{mV}$ with steps of $5 \mathrm{mV}$ (holding potential was $-60 \mathrm{mV}$ ) and durations of $0.5-1 \mathrm{~s}$. The slope conductance was calculated by measuring the slope of the $I-V$ relationship curve between -80 and $-50 \mathrm{mV}$. $I-V$ relationships of kisspeptin-sensitive currents were generally obtained by subtracting the $I-V$ curve in control condition from that in the presence of kisspeptin.

To display the reversal potential and rectification characteristics of the kisspeptin-activated cationic currents, $I-V$ plots were usually constructed by ramp voltage commands: the membrane potential was first stepped from a holding potential of -50 to $+60 \mathrm{mV}$, held for $1 \mathrm{~s}$ and then ramped to $-80 \mathrm{mV}$ in $10 \mathrm{~s}$. The access resistance was kept $<15 \mathrm{M} \Omega$ and was $60-80 \%$ compensated. For experiments in low sodium bath, some $I-V$ plots were also constructed by ramp voltage commands with the membrane potential first being stepped from a holding potential of -60 to $-20 \mathrm{mV}$, held for $1 \mathrm{~s}$, and then ramped to $-120 \mathrm{mV}$ in $5 \mathrm{~s}$.

Electrophysiological solutions/drugs. Normal aCSF (in mm: $124 \mathrm{NaCl}, 5$ $\mathrm{KCl}, 2.6 \mathrm{NaH}_{2} \mathrm{PO}_{4}, 2 \mathrm{MgCl}_{2}, 2 \mathrm{CaCl}_{2}, 26 \mathrm{NaHCO}_{3}, 10 \mathrm{HEPES}, 10$ glucose) was used in most cases for electrophysiological recording. High- $\mathrm{K}^{+}(15 \mathrm{~mm})$ CSF was prepared by increasing the potassium concentration while decreasing the sodium concentration of the normal aCSF. When cationic blockers such as $\mathrm{Ba}^{2+}, \mathrm{Cd}^{2+}$, and $\mathrm{La}^{3+}$ were added to bath, HEPES-buffered CSF (phosphate- and carbonate-free) solution with following composition was used (in mM): $145 \mathrm{NaCl}, 5 \mathrm{KCl}, 2 \mathrm{MgCl}_{2}$, $2 \mathrm{CaCl}_{2}, 10 \mathrm{HEPES}, 10$ glucose. Low $\mathrm{Na}^{+}$extracellular solution was prepared by replacing $\mathrm{NaCl}$ of the HEPES-buffered CSF with equivalent concentration of $\mathrm{N}$-methyl-D-glucamine (NMDG) and $\mathrm{HCl}$. In a subset of experiments studying the $I-V$ relationship of the kisspeptin-activated nonselective cationic channel (NSCC) when potassium channel blockers [0-20 mm tetraethylammonium (TEA), $5 \mathrm{~mm} 4-\mathrm{AP}, 1 \mathrm{~mm} \mathrm{CsCl}, 0-0.3$ $\mathrm{mM} \mathrm{BaCl}_{2}$ ] were included in HEPES-buffered CSF, sodium was partially replaced to maintain the osmolarity. To eliminate the effect of voltagegated calcium current on the $I-V$ relationship and reversal potential of the nonselective cationic current, extracellular $\mathrm{Ca}^{2+}$ was either replaced by $\mathrm{Mg}^{2+}$ or calcium channel blockers $(10 \mu \mathrm{M}$ nifedipine and $100 \mu \mathrm{M}$ $\mathrm{Cd}^{2+}$ ) were added to the bath. HEPES-buffered solutions were oxygenated by medical oxygen.

Normal pipette solution contained the following (in mM): 125 potassium gluconate, $10 \mathrm{NaCl}, 1 \mathrm{MgCl}_{2}$, 11 EGTA, 10 HEPES, 2 MgATP, 2 $\mathrm{K}_{2}$ ATP, 0.25 GTP, adjusted to $\mathrm{pH} 7.3$ with $\mathrm{KOH}, 295 \mathrm{mOsm}$. High chloride $(38 \mathrm{~mm})$ pipette solution was prepared by replacing $25 \mathrm{~mm}$ potassium gluconate with $25 \mathrm{~mm} \mathrm{KCl}$. Cesium-based pipette solution used for nonselective cationic current recording was prepared by replacing potassium with cesium and adjusting to $\mathrm{pH} 7.3$ with $\mathrm{CsOH}$ (295 mOsm). In whole-cell current-clamp and voltage-clamp recordings, 0.5-1 $\mu \mathrm{M}$ TTX was used to eliminate the effect of presynaptic input.

Different drug stocks were 1000 times diluted into CSF to their final concentrations in $20 \mathrm{ml}$ syringes and were delivered by a Gilson MiniPlus Pump with a perfusion rate of $1.5 \mathrm{ml} / \mathrm{min}$. The ion channel blockers/ activators used are as follows [from Sigma-Aldrich (St. Louis, MO) unless otherwise noted]: kisspeptin-10 [Mouse KiSS-1(110-119)- $\mathrm{NH}_{2}$; Phoenix Pharmaceuticals, Belmont, CA], $\mathrm{LaCl}_{3}(100 \mu \mathrm{M}), 2$-aminoethyl 
Table 1. Primer sequences used for single-cell RT-PCR

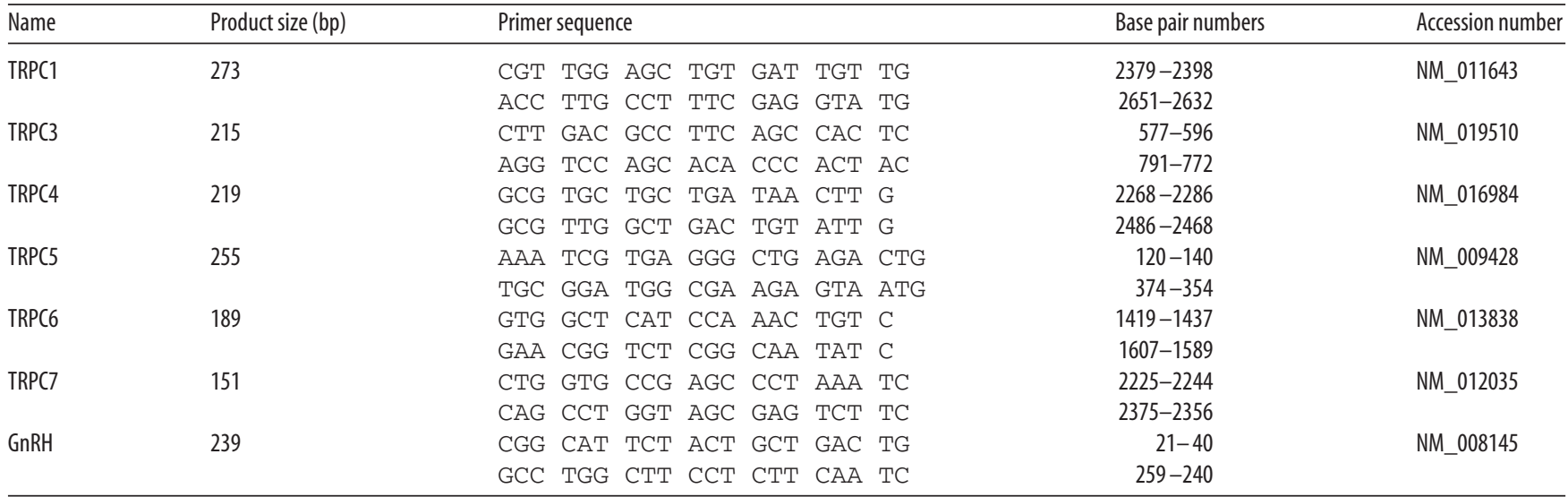

The forward primer is listed first, and the reverse primer is listed second.

diphenylborinate (2-APB) $(100 \mu \mathrm{M}), \mathrm{CdCl}_{2}(250 \mu \mathrm{M}), 1-[\beta-[3-(4-$ methoxyphenyl)propoxy]-4-methoxyphenethyl]-1 $H$-imidazole hydrochloride (SKF96365) (30 $\mu \mathrm{M}$ ), flufenamic acid (FFA) (100 $\mu \mathrm{M})$, and TTX (0.5-1 $\mu \mathrm{M}$; Alomone Laboratories, Jerusalem, Israel).

Electrophysiology data analysis. Data were analyzed using p-Clamp software (version 9.2; Molecular Devices). All reported membrane potentials were corrected by $-10 \mathrm{mV}$ (liquid junction potential). Statistical analysis was performed using GraphPad Prism 4 software (GraphPad Software, San Diego, CA). Comparisons between different treatments were performed using a one-way ANOVA analysis with the Bonferroni's or Tukey's post hoc test. Differences were considered statistically significant if the probability of error was $<5 \%$. All data are presented as mean \pm SEM.

Cell harvesting of dispersed GnRH neurons and single-cell RT-PCR. Two to three $300 \mu \mathrm{m}$ DB-POA slices were cut on a vibratome and placed in an auxiliary chamber containing oxygenated aCSF. The slices were allowed to recover for $1-2 \mathrm{~h}$ in the chamber before dispersion. A discrete region of the diagonal band-rostral POA was microdissected and incubated in 5-10 ml of aCSF $\left(124 \mathrm{~mm} \mathrm{NaCl}, 5 \mathrm{~mm} \mathrm{KCl}, 2.6 \mathrm{~mm} \mathrm{NaH}_{2} \mathrm{PO}_{4}, 2 \mathrm{~mm}\right.$ $\mathrm{MgSO}_{4}, 2 \mathrm{~mm} \mathrm{CaCl}_{2}, 26 \mathrm{~mm} \mathrm{NaHCO}_{3}, 10 \mathrm{~mm}$ HEPES, $10 \mathrm{~mm}$ D-glucose, in DEPC-treated water, $\mathrm{pH} 7.3,300 \mathrm{mOsm}$ ) containing $1 \mathrm{mg} / \mathrm{ml}$ protease for $\sim 17 \mathrm{~min}$ at $37^{\circ} \mathrm{C}$. The tissue was then washed four times in low calcium CSF $\left(0.1 \mathrm{~mm} \mathrm{CaCl}_{2}\right)$ and two times in aCSF. The cells were isolated by trituration with flame-polished Pasteur pipettes. The cells were dispersed onto a $60 \mathrm{~mm}$ Petri dish, and were visualized under a Nikon (Tokyo, Japan) inverted microscope equipped with fluorescence. Fluorescent cells or adjacent nonfluorescent cells were patched and then harvested into the patch pipette by applying negative pressure. The contents of the pipette were expelled into a siliconized microcentrifuge tube containing $1 \mu \mathrm{l}$ of $5 \times$ Colorless GoTaq Flexi buffer (Promega, Madison, $\mathrm{WI}), 15 \mathrm{U}$ of Rnasin, $0.5 \mu \mathrm{l}$ of $100 \mathrm{~mm}$ DTT, and DEPC-treated water in a total volume of $5 \mu \mathrm{l}$. Each harvested cell was reverse transcribed as described previously (Ibrahim et al., 2003; Qiu et al., 2003). Briefly, the harvested cell solution and $25 \mathrm{ng}$ of hypothalamic total RNA in $5 \mu$ l were denatured for $5 \mathrm{~min}$ at $65^{\circ} \mathrm{C}$, and then cooled on ice for $5 \mathrm{~min}$. Singlestranded cDNA was synthesized from cellular RNA by adding $50 \mathrm{U}$ of murine leukemia virus reverse transcriptase (MuLV-RT) (Applied Biosystems, Foster City, CA), $3 \mu$ l of $5 \times$ Colorless GoTaq Flexi buffer, $5 \mathrm{~mm}$ $\mathrm{MgCl}_{2}, 0.625 \mathrm{~mm}$ dNTPs, $15 \mathrm{U}$ of Rnasin, $10 \mathrm{~mm}$ DTT, and $100 \mathrm{ng}$ of random hexamers in a total of $15 \mu \mathrm{l}$ of DEPC-treated water for a final volume of $20 \mu \mathrm{l}$. Cells and tissue RNA used as negative controls, were processed as described above, but without MuLV-RT. The reaction mixtures were incubated at $42^{\circ} \mathrm{C}$ for $60 \mathrm{~min}$, denatured at $95^{\circ} \mathrm{C}$ for $5 \mathrm{~min}$, and cooled on ice for $5 \mathrm{~min}$. PCR was performed using $2.75 \mu \mathrm{l}$ of cDNA template from each RT reaction in a $30 \mu$ l of PCR mix containing the following: $6 \mu \mathrm{l}$ of $5 \times$ buffer (Promega), $2-3 \mathrm{~mm} \mathrm{MgCl}_{2}, 0.33 \mathrm{~mm} \mathrm{dNTP \text {, }}$ $0.33 \mu \mathrm{M}$ forward and reverse primers, $2 \mathrm{U}$ of TaqDNA polymerase and TaqStart antibody (Clontech, Palo Alto, CA). TaqDNA polymerase and TaqStart antibody were combined and incubated at room temperature for $5 \mathrm{~min}$ and the remainder of the reaction content was added to the tube. Primers for all TRPC channels were designed and tested using known mouse sequences. All primers were designed to span introns and synthesized by Invitrogen (Carlsbad, CA) using Clone Manager 5 software (Sci Ed Software, Cary, NC). For a listing of all the primer sets used for scRT-PCR, see Table 1 . PCR products were verified by sequencing. Each reaction was amplified for 50 cycles using a MJ Research (Watertown, MA) PTC-100 thermocycler in $0.5 \mathrm{ml}$ of thin-walled PCR tubes according to protocols optimized for each primer pair. Ten microliters of PCR product was visualized with ethidium bromide on a $2.5 \%$ agarose gel. TRPC2 subunits were not examined because the expression and function of this subunit is associated primarily with olfactory neurons in rodents (Liman et al., 1999; Hofmann et al., 2000).

\section{Results}

\section{Kisspeptin depolarizes GnRH neurons in a} concentration-dependent manner

The depolarizing effects of kisspeptin in $\mathrm{GnRH}$ neurons have been reported previously, but the concentration-response relationship has not been established (Han et al., 2005; Quaynor et al., 2007; Pielecka-Fortuna et al., 2008). Therefore, in the first series of experiments, we studied the concentration-dependent depolarization of GnRH neurons by kisspeptin. Membrane potentials were measured under whole-cell current-clamp conditions and in the presence of TTX $(0.5-1.0 \mu \mathrm{M})$. The mean resting membrane potential of $\mathrm{GnRH}$ neurons was $-63.6 \pm 0.6 \mathrm{mV}$. As shown in Figure 1, $A$ and $B$, kisspeptin-10 depolarized GnRH neurons in a concentration-dependent manner and $>90 \%$ of cells responded to $100 \mathrm{~nm}$ kisspeptin. The $\mathrm{EC}_{50}$ for the kisspeptininduced depolarization was $2.8 \pm 0.2 \mathrm{~nm}$. The maximum depolarization evoked by kisspeptin was $22.6 \pm 0.6 \mathrm{mV}$. In the presence of kisspeptin (100 nM), the mean slope conductances between -50 and $-80 \mathrm{mV}$ decreased from $1.0 \pm 0.1$ to $0.3 \pm 0.1$ $\mathrm{nS}(n=12)$. As reported previously (Han et al., 2005), the effect of kisspeptin in the hypothalamic slice was longlasting, with recovery normally taking $\sim 30 \mathrm{~min}$ (Fig. $1 C$ ). Therefore, only one cell was recorded from each slice and only one concentration of kisspeptin was applied to each cell.

\section{Kisspeptin inhibits a Kir channel and activates a nonselective cationic channel}

To characterize the ionic mechanism(s) underlying the kisspeptin-evoked depolarization, the kisspeptin-induced inward currents were recorded at a holding potential of $-60 \mathrm{mV}$, which closely approximates the resting membrane potential of these neurons, followed by an analysis of the reversal potentials of the kisspeptin-induced currents (Zhang et al., 2007). A saturating 
A

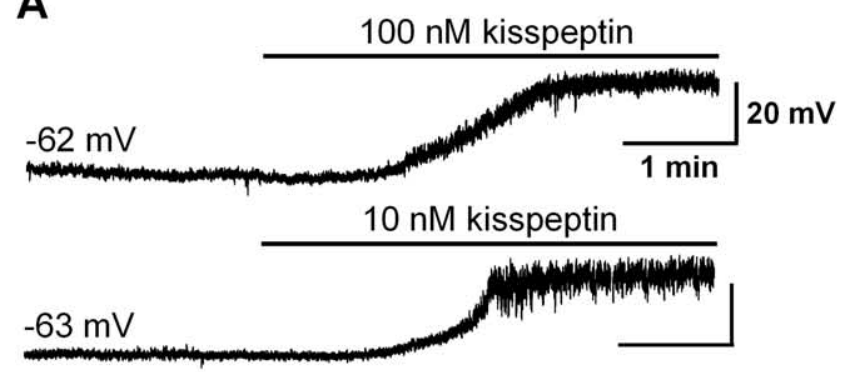

3 nM kisspeptin

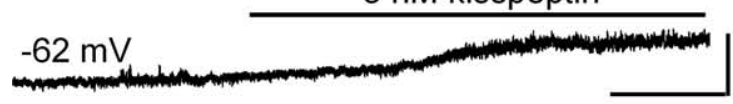

$1 \mathrm{nM}$ kisspeptin

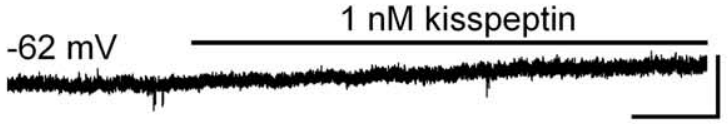

B

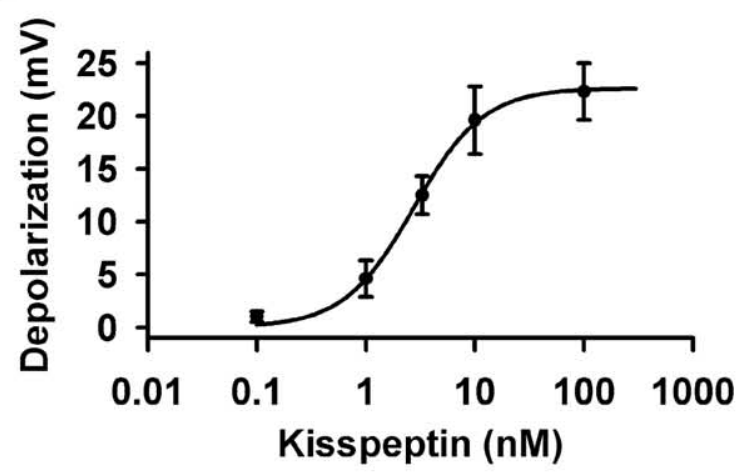

C

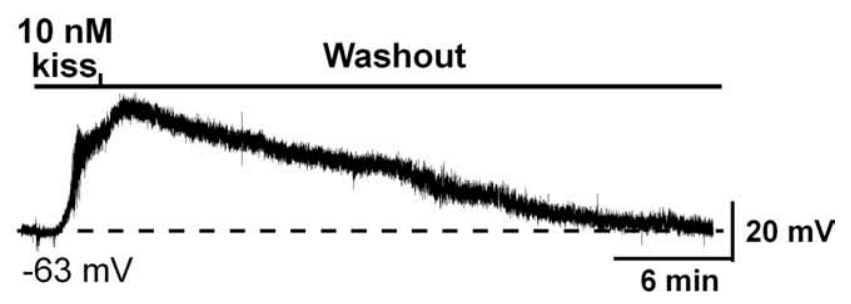

Figure 1. Kisspeptin depolarized GnRH neurons in a concentration-dependent manner. $A$, Representative traces showing that kisspeptin (1-100 nm) depolarized GnRH neurons in a concentration-dependent manner. The initial membrane potential for each trace is indicated. Only one cell was recorded from one slice. $\boldsymbol{B}$, Concentration-response curve of the kisspeptininduced depolarization. Data are presented as mean $\pm \mathrm{SEM}$. The $\mathrm{EC}_{50}$ for the kisspeptininduced depolarization was $2.8 \pm 0.2 \mathrm{~nm}(n=8-14)$ based on a logistic equation fit to the data points. C, The kisspeptin (10 nm)-induced depolarization was longlasting and typically took $30 \mathrm{~min}$ to recover.

concentration of kisspeptin (100 nM) was used to ensure a maximum response and to avoid any potential fluctuation of the effective peptide concentration. As shown in Figure 2A, $100 \mathrm{~nm}$ kisspeptin induced an inward current with a peak amplitude of 20 pA. $I-V$ relationships were obtained immediately before kisspeptin application and after the kisspeptin-induced inward currents reached their plateau (Fig. 2 B1,C1). To clearly show the reversal potential, the $I-V$ relationship of the kisspeptin-sensitive current (I-kiss) was constructed by subtracting the $I-V$ relationship before kisspeptin application (control) from that in the presence of kisspeptin (100 nm Kiss) (Fig. 2 B, C). As shown in Figure 2, B2 and $C 2$, the kisspeptin-evoked currents reversed at potentials more negative than $E_{\mathrm{K}}{ }^{+}(-90 \mathrm{mV})$. In $\sim 55 \%$ of the cells (12 of $22)$, the negative reversal potentials were between -90 and -120 $\mathrm{mV}(-102.9 \pm 2.4 \mathrm{mV} ; n=12)$ (Fig. $2 B)$. In the other $45 \%$ of the cells, the apparent negative reversal potential was below -120 $\mathrm{mV}$ (Fig. 2C). The composite $I-V$ curve for the kisspeptininduced currents revealed a reversal potential of $-115 \mathrm{mV}$, which is $25 \mathrm{mV}$ more negative than the predicted $E_{\mathrm{K}}{ }^{+}$(Fig. $2 \mathrm{D}$ ).

To test the dependence of the kisspeptin-induced inward current on potassium, the extracellular potassium concentration was increased from 5 to $15 \mathrm{~mm}$, and the reversal potential of the kisspeptin-induced inward currents was measured. The predicted equilibrium potential for potassium $\left(E_{\mathrm{K}}{ }^{+}\right)$should shift from -90 to $-60 \mathrm{mV}$ when the extracellular potassium concentration is increased. The composite $I-V$ curve for the kisspeptininduced current in $15 \mathrm{mM} \mathrm{K}^{+}$revealed a reversal potential of $-105 \mathrm{mV}$ (data not shown). The reversal potential shifted by only $10 \mathrm{mV}$, which is less than the predicted $30 \mathrm{mV}$ shift of the equilibrium potential for potassium. The access resistance in cells exhibiting a reversal $(17.7 \pm 1.1 \mathrm{M} \Omega)$ was identical with cells not showing a reversal $(17.5 \pm 1.1 \mathrm{M} \Omega)$, indicating that the more negative reversal compared with $E_{\mathrm{K}}{ }^{+}$was not caused by clamping error. A potential explanation for the more negative reversal potential than $E_{\mathrm{K}}{ }^{+}$is that a potassium channel and a NSCC are both affected by kisspeptin, and the combined activation of a NSCC current and inhibition of a potassium current results in an apparent reversal for the composite kisspeptin-sensitive current that is shifted to more negative potentials.

It is well known that kisspeptins activate a Gq-coupled orphan receptor GPR54 (Kotani et al., 2001; Muir et al., 2001; Stafford et al., 2002), and potassium channels, in particular Kir channels, are regulated by Gq-coupled receptors (Velimirovic et al., 1995; Lei et al., 2001; Carr and Surmeier, 2007). To test the involvement of Kir channels, the Kir channel blocker barium was applied to cells and its effect on the reversal potentials of the kisspeptin-induced currents was analyzed. Micromolar extracellular barium is a robust blocker of the inward current of Kir channels; however, submillimolar barium concentrations are required to block the outward currents of the Kir channels (Lacey et al., 1988; Owen et al., 1999; Slugg et al., 1999). To block both the inward and outward currents of the Kir channels, a barium concentration of 0.3 mM was used because this concentration blocks the outward current of the Kir channels by at least $80 \%$ while having little effect on other potassium channels (Lacey et al., 1988; Slugg et al., 1999; Carr and Surmeier, 2007). As illustrated in Figure $3 A$, the $I-V$ relationships clearly show that $0.3 \mathrm{~mm}$ barium robustly inhibited the outward as well as the inward component of the Kir currents in GnRH neurons. After blocking the Kir currents with extracellular barium or internal $\mathrm{Cs}^{+}$, the kisspeptin-induced currents only reversed near $0 \mathrm{mV}$ (Fig. $3 B, C$ ), which indicates that not only the Kir channels were inhibited by kisspeptin but also a nonselective cationic channel was activated by kisspeptin.

\section{NSCC current is the dominant inward current that is} activated by kisspeptin

To determine the relative contribution of a nonselective cationic channel to the kisspeptin-induced inward current around the resting membrane potential, the effects of potassium channel blockers on the kisspeptin-induced inward current at $-60 \mathrm{mV}$ were examined. As shown in Figure $3 D$, the kisspeptin-induced currents in the presence of extracellular barium (20.6 $\pm 4.5 \mathrm{pA}$; $n=9)$ and internal $\mathrm{Cs}^{+}(18.0 \pm 1.4 \mathrm{pA} ; n=9)$ were not signif- 
A

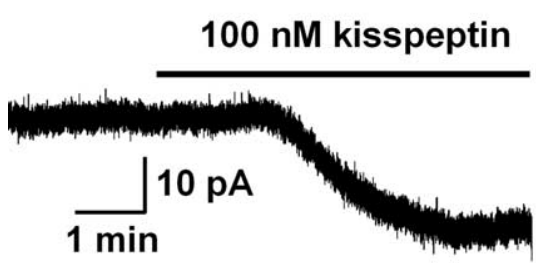

B1

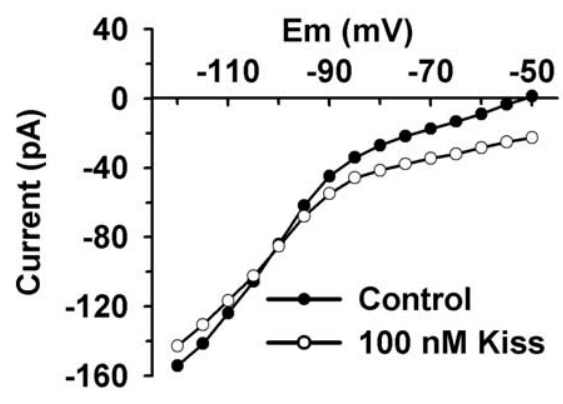

B2

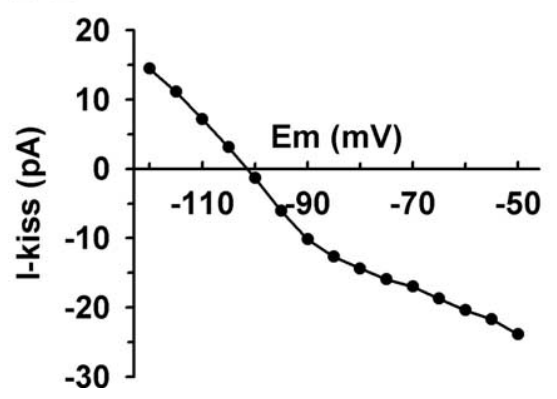

C2

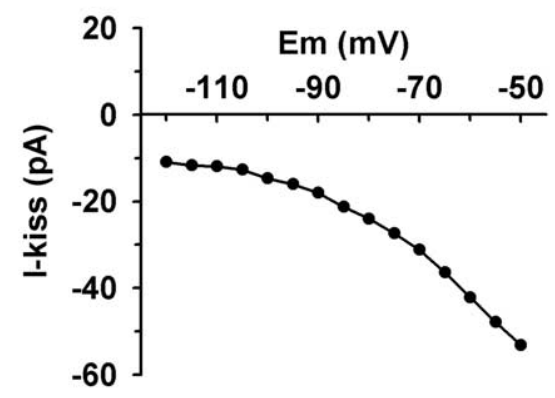

C1

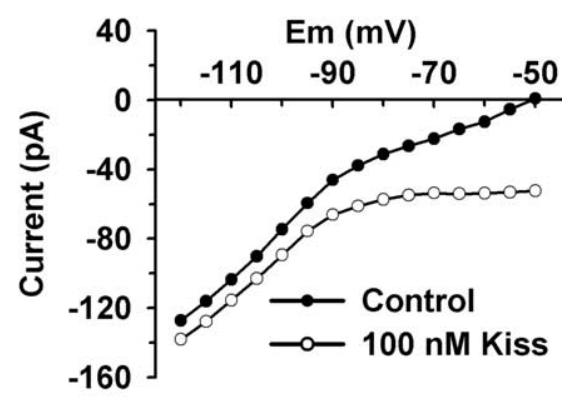

D

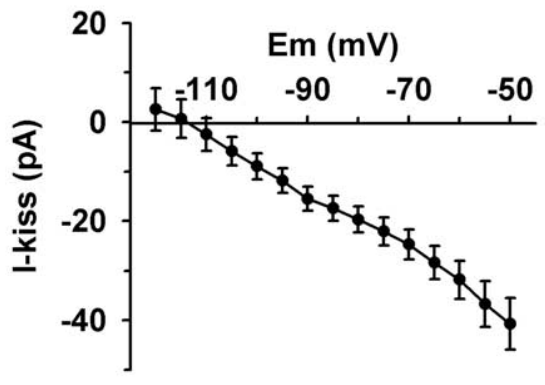

Figure 2. The reversal potential of the kisspeptin-evoked inward current was more negative than the equilibrium potential of potassium $\left(E_{\mathrm{K}}{ }^{+}\right) \cdot A$, A representative trace showing that kisspeptin $(100 \mathrm{~nm})$ induced an inward current $(20 \mathrm{pA})$ at the holding potential of $-60 \mathrm{mV}$. $\boldsymbol{B}, \operatorname{In} 55 \%$ (12 of 22) of the cells, the kisspeptin-induced current reversed between -90 and $-110 \mathrm{mV}$. B1 shows that the typical $I-V$ curves obtained before and after the application of kisspeptin crossed at $-102 \mathrm{mV}$. B2 shows that the $I-V$ curve of the kisspeptin-sensitive current (I-kiss) from $B$ 1, which was obtained by subtracting the control current from the current in $100 \mathrm{~nm}$ kisspeptin, reversed at $-102 \mathrm{mV}$. C, In the other $45 \%$ of the cells, the kisspeptin-induced current did not reverse between -90 and $-120 \mathrm{mV}$. C 1 shows that the representative $I-V$ curves obtained before and after the application of kisspeptin did not cross around $E_{\mathrm{K}}{ }^{+}$. C 2 shows that the kisspeptin-sensitive current obtained from $C 1$ by current subtraction did not reverse in the examined voltage range. $\boldsymbol{D}$, Composite $I-V$ curve of the kisspeptin-sensitive currents reversed at $-115 \mathrm{mV}$ $(n=13)$. Error bars indicate SEM.

icantly different from that in control CSF $(18.2 \pm 1.6 \mathrm{pA} ; n=29)$. This indicates that NSCC but not potassium channels are the predominant component modulated by kisspeptin. As we know in physiological conditions, the inward current of a NSCC is mainly mediated by extracellular sodium. Thus, to verify the contribution of sodium-dependent NSCC to the kisspeptin-induced inward current, extracellular $\mathrm{Na}^{+}$was reduced to 15 or $5 \mathrm{~mm}$ from $145 \mathrm{~mm}$ by replacing extracellular $\mathrm{Na}^{+}$with $\mathrm{NMDG}^{+}$, a large organic cation that does not pass through cationic channels. Under these conditions, the kisspeptin-induced inward currents were greatly inhibited (Fig. 4). The inward current at $-60 \mathrm{mV}$ decreased from a mean value of $20.7 \pm 2.1 \mathrm{pA}(n=9)$ in the control CSF bath to $4.4 \pm 1.7 \mathrm{pA}(n=5 ; p<0.001)$ in $15 \mathrm{~mm}$ $\mathrm{Na}^{+}$and $1.3 \pm 0.4 \mathrm{pA}(n=9 ; p<0.001)$ in $5 \mathrm{mM} \mathrm{Na}^{+}$bath (Fig. $4 E)$. Therefore, the sodium-dependent NSCC current appears to be the predominant inward current activated by kisspeptin. Although the contribution of potassium channels to the kisspeptin-induced inward current was negligible around the resting membrane potential $(<6.3 \%$ at $-60 \mathrm{mV})$, they strongly affected the reversal potential of the kisspeptin-induced current at hyperpolarized potentials.

\section{TRPC-like channels are activated by kisspeptin in GnRH neurons}

The above results clearly indicate that nonselective cationic channels were the predominant channels activated by kisspeptin. Among the NSCC that are activated by Gqcoupled receptor signaling, TRPC channels are the most prominent candidates (Clapham, 2003). To test this idea, two sets of experiments were conducted. First, we examined the $I-V$ relationship of the kisspeptin-activated currents, and then we examined the sensitivity of the kisspeptinactivated currents to TRPC channel blockers.

To examine the $I-V$ relationship of the kisspeptin-activated NSCC currents over a more complete range of membrane potentials, these experiments were conducted using a $\mathrm{Cs}^{+}$-gluconate-based internal solution to block voltage-gated potassium channels. Also, 4-AP (5 mM) and cesium (1 $\mathrm{mM})$ were included in a HEPES-buffered CSF to block the A-type potassium and hyperpolarization-activated (h) currents, respectively. Voltage-gated calcium currents were maximally activated around 0 $\mathrm{mV}$ and their rundown will affect the actual reversal potential of a NSCC activated by kisspeptin (Fig. 4D). Therefore, to avoid the effect of voltage-gated calcium currents on the reversal measurement extracellular calcium was replaced with magnesium or calcium channel blockers $\left(100 \mu \mathrm{M} \mathrm{Cd}^{2+}\right.$ and $10 \mu \mathrm{M}$ nifedipine) were added to the extracellular solution. As shown in Figure $5, A-C$, the kisspeptin-activated NSCC currents reversed near $0 \mathrm{mV}(-3.8 \pm 4.4 \mathrm{mV}$; $n=12)$. Extracellular calcium did not affect the amplitude of the kisspeptin-activated current. However, extracellular TEA (20 $\mathrm{mm}$ ) reduced the amplitude of the kisspeptin-activated current but did not affect the $I-V$ relationship (Fig. $5 B$ ), which is consistent with a previous report on the muscarine-activated NSCC (Haj-Dahmane and Andrade, 1996). In 75\% (9 of 12) of the cells, the $I-V$ relationship of the kisspeptin-activated currents showed a negative slope conductance at voltages more negative than $-40 \mathrm{mV}$ (Fig. $5 A, C$ ), which resembles TRPC heteromers of TRPC1 plus TRPC4 and TRPC1 plus TRPC5. In another $25 \%$ of cells, the $I-V$ relationship of the kisspeptin-activated currents exhibited double rectification and a positive slope conductance (Fig. 5D), which resembles $I-V$ relationships for TRPC3 or TRPC7 (Clapham et al., 2001).

To examine whether the kisspeptin-activated currents were 
sensitive to TRPC channel blockers, an ensemble of TRPC channel blockers were applied to GnRH neurons, and the kisspeptin-activated inward currents at $-60 \mathrm{mV}$ were measured and analyzed. For example, 2-APB is a potent blocker of TRPC3, TRPC4, TRPC5, and TRPC6 (van Rossum et al., 2000; Xu et al., 2005; Clapham, 2007). In our experiments, extracellularly applied 2-APB $(100 \mu \mathrm{M})$ robustly blocked the kisspeptin-induced currents by $83.5 \%(3.0 \pm 1.0 \mathrm{pA}, n=9$, vs control, $18.2 \pm 1.6 \mathrm{pA}, n=29, p<0.001)$ regardless of whether it was applied before or after the application of kisspeptin (Fig. 6A-D). 2 -APB had very little effect on the basal holding current, indicating that potassium channels were not blocked by 2-APB (Fig. $6 A)$. As shown in Figure $6 B$, after blocking TRPC channels with 2-APB, the kisspeptininduced currents were inwardly rectified and reversed at $-90 \pm 3 \mathrm{mV}(n=4)$, which indicates the inhibition of the Kir channels. However, 2-APB is also a blocker of inositol-1,4,5-trisphosphate $\left(\mathrm{IP}_{3}\right)$ receptors (van Rossum et al., 2000). To determine whether the inhibitory effect of 2-APB is attributable to a direct blockade of TRPC channels or $\mathrm{IP}_{3}$ receptors, 2-APB $(100 \mu \mathrm{M})$ was dialyzed into the cells via the patch pipette. Intracellular 2-APB did not significantly affect the amplitude of the kisspeptin-induced inward current $(16.0 \pm$ $2.9 \mathrm{pA} ; n=4)$. This indicates that 2-APB blocked the kisspeptin response by directly acting on TRPC channels but not via $\mathrm{IP}_{3}$ receptors.

In heterologous expression systems, micromolar concentrations of $\mathrm{La}^{3+}$ potentiate TRPC4 and TRPC5 activity (Schaefer et al., 2000; Strübing et al., 2001; Jung et al., 2003) but inhibit TRPC1, TRPC3, TRPC6, and TRPC7 channels (Boulay et al., 1997; Zhu et al., 1998; Kamouchi et al., 1999; Okada et al., 1999; Halaszovich et al., 2000; Inoue et al., 2001; Riccio et al., 2002; Clapham, 2007). We found that $100 \mu \mathrm{M} \mathrm{La}^{3+}$ did not potentiate but slightly attenuated the kisspeptin-induced current by $17.4 \%$ $(15.0 \pm 2.0 ; n=5 ; p>0.05)$ when applied after the application of kisspeptin (Fig. 6D). SKF96365 is an inhibitor of receptoroperated calcium channels and TRPC channels at concentration of 25-100 $\mu \mathrm{M}$ (Merritt et al., 1990; Zhu et al., 1998). We found that $30 \mu \mathrm{M}$ SKF96365 attenuated the kisspeptin-induced inward current by $50 \%(9.1 \pm 1.6 \mathrm{pA} ; n=9 ; p<0.01)$. Cadmium is an antagonist of group I metabotropic glutamate receptor (mGluR1)-activated NSCC in CA1 pyramidal neurons and also blocks TRPC6 and TRPC7 (other TRPC channels have not been tested) in heterologous expression systems (Congar et al., 1997; Inoue et al., 2001). Indeed, we found that $250 \mu \mathrm{M} \mathrm{Cd}{ }^{2+}$ attenuated the kisspeptin-induced current by $68.7 \%$ (5.7 \pm $1.6 \mathrm{pA} ; n=4)$. FFA is potent blocker of TRPC3, TRPC5 and TRPC7 (Inoue et al., 2001; Lee et al., 2003; Clapham, 2007). When cells were pretreated with $100 \mu \mathrm{M}$ FFA for $20 \mathrm{~min}$, the kisspeptin-induced inward current was blocked by $89.6 \%$ $(1.9 \pm 1.1 \mathrm{pA} ; n=8)$ (Fig. $6 \mathrm{D})$. Collectively, these data indicate that multiple members of the TRPC channel subfamilies are activated by kisspeptin.
B

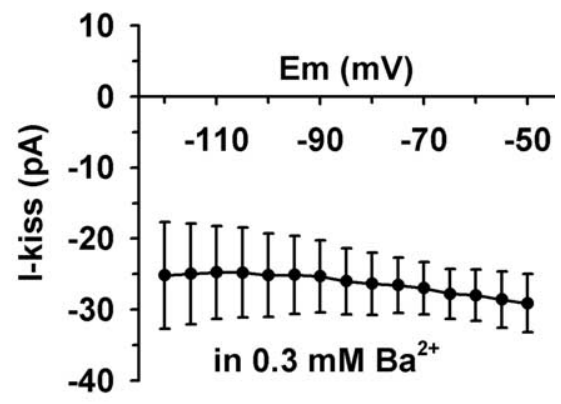

D

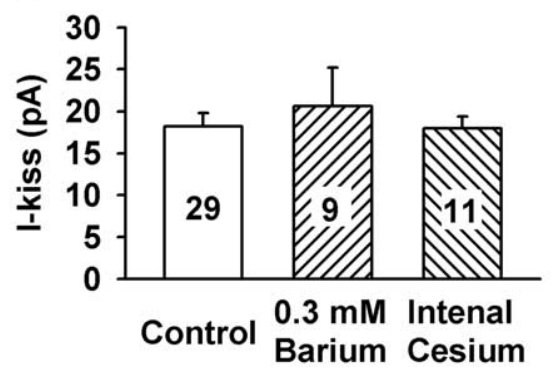

Figure 3. Kisspeptin inhibited an inwardly rectifying potassium (Kir) current and activated a nonselective cationic current. $A$, The composite $I-V$ relationships indicate that extracellular $\mathrm{Ba}^{2+}(0.3 \mathrm{~mm})$ blocked Kir channels in GnRH neurons $(n=6) . \boldsymbol{B}$, In the presence of the Kir channel blockade $\left(0.3 \mathrm{~mm} \mathrm{Ba}^{2+} ; n=8\right)$, the kisspeptin-activated current did not reverse around $E_{\mathrm{K}}{ }^{+}$ ( $)$, which indicates the activation of a nonselective cationic channel. $C$, When recorded with cesium-based internal solution Both the barium group and the internal cesium group are not significantly different from the control group $(p>0.05)$. Cell numbers tested are indicated. Error bars indicate SEM.

Finally, the predominant role of the TPRC channels in mediating the effects of kisspeptin is evident from a plot of the additive $I-V$ relationship (Fig. 7). The sum of the kisspeptin-inhibited Kir current and the kisspeptin-activated NSCC current yields an apparent reversal significantly more negative than $E_{\mathrm{K}}{ }^{+}$in the voltage range from -50 to $-120 \mathrm{mV}$. Similarly, the sum of the Kir and NSCC currents would yield a positive reversal near $0 \mathrm{mV}$ (data not shown). Therefore, this cumulative $I-V$ of the individual parts resembles the $I-V$ relationship of Figure $2 D$, which supports our original hypothesis that these two conductances (Kir and NSCC) are involved but that NSCC predominates.

\section{TRPC channel transcripts are expressed in GnRH neurons}

Based on the pharmacological profile of the kisspeptin-evoked inward currents, we predicted that multiple subfamilies of the TRPC channels would be expressed in GnRH neurons. Thus, we performed scRT-PCR experiments to examine the expression of TRPC mRNA transcripts in $48 \mathrm{GnRH}$ neurons from four intact animals. As shown in Figure $8, A$ and $B$, the six main TRPC channel subunits in the brain (TRPC1 and TRPC3-TRPC7) were expressed in subpopulations of GnRH neurons. Fifty to $55 \%$ of GnRH neurons expressed TRPC7 and TRPC4, respectively, whereas TRPC1, TRPC3, and TRPC5 were expressed in $\sim 45 \%$ of GnRH neurons (Fig. 8 B). TRPC6 was detected in $\sim 28 \%$ of the cells. Adjacent nonfluorescent neurons $(n=9)$ did not express GnRH, TRPC1 or TRPC6, but expressed TRPC3, TRPC4, TRPC5, and TRPC7 (Fig. 8). 
A

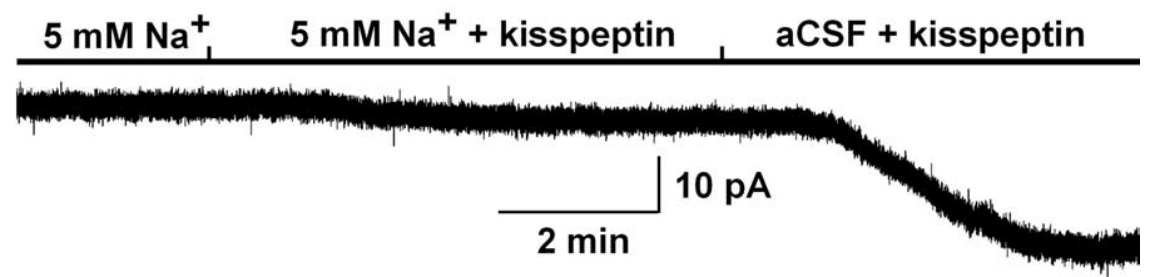

B

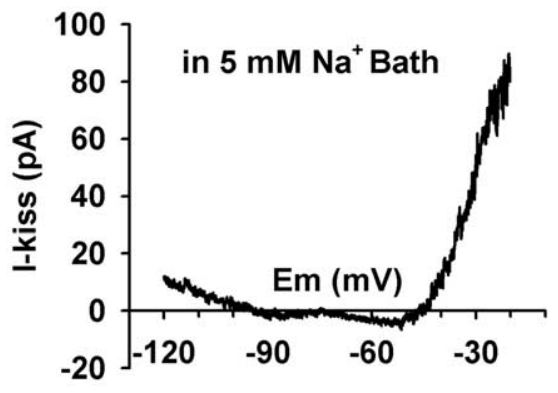

C

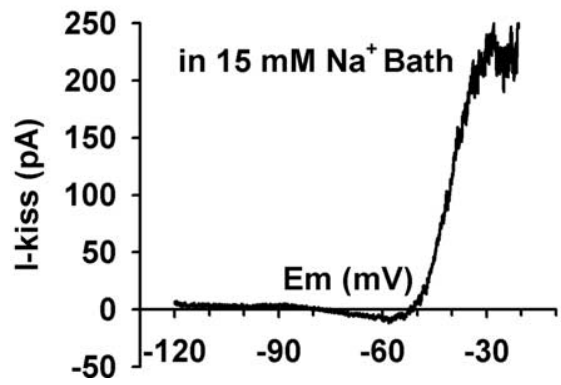

D

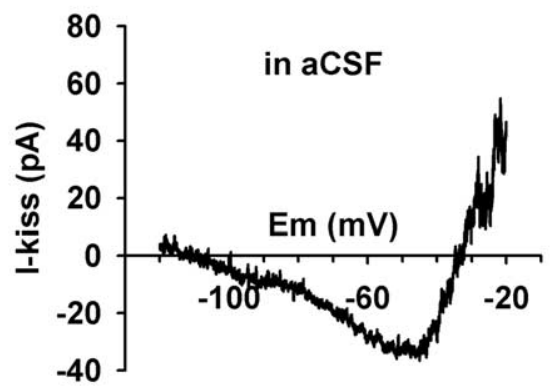

E

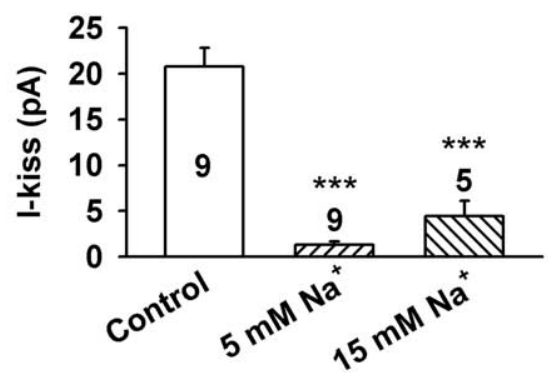

Figure 4. Kisspeptin predominantly activated a sodium-dependent, nonselective cationic channel. $\boldsymbol{A}$, The kisspeptin-induced inward current (at $-60 \mathrm{mV}$ ) was greatly reduced in low $\mathrm{Na}^{+}$bath solution $\left(5 \mathrm{~mm} \mathrm{Na}{ }^{+} / 140 \mathrm{~mm} \mathrm{NMDG}{ }^{+}\right.$), and switching back to normal aCSF revealed a kisspeptin-sensitive inward current of $28 \mathrm{pA}$ in this $\mathrm{GnRH}$ neuron. $\boldsymbol{B}, \boldsymbol{C}$, The $I-V$ relationships of the kisspeptin-evoked current in low $\mathrm{Na}^{+}$bath solution $\left(5\right.$ and $15 \mathrm{~mm} \mathrm{Na}^{+}$) between -20 and $-120 \mathrm{mV}$ showed a greatly reduced inward current. $D, A$ typical $I-V$ relationship of the kisspeptin-induced inward current in normal aCSF solution showed a larger inward current $(-30 \mathrm{pA}$ at $-60 \mathrm{mV})$. $\boldsymbol{E}$, Summary of the effect of extracellular sodium concentration on the kisspeptin-induced inward current at $-60 \mathrm{mV}$. ${ }^{* *} p<0.001$, significantly different from the control group. Cell numbers tested are indicated. Error bars indicate SEM.

Diacylglycerol signaling is involved in the kisspeptin-induced inward currents

To verify that the kisspeptin receptor GPR54 couples to Gq and phospholipase C (PLC) pathway in GnRH neurons, the effect of the PLC inhibitor 1-(6-[(17 $\beta$-methoxyestra-1,3,5[10]-trien-17yl)amino]hexyl)-1 $H$-pyrrole-2,5-dione (U73122) on the kisspeptin-induced inward current was examined. When cells were pretreated with $10 \mu \mathrm{M} \mathrm{U} 73122$ for $10 \mathrm{~min}$, the kisspeptininduced inward current was inhibited by $63.7 \%(6.6 \pm 2.1 \mathrm{pA}$; $n=4)$. This indicates that GPR54 couples to Gq, and PLC activation is required to induce the inward currents. PLC hydrolyzes $\mathrm{PIP}_{2}$ to yield diacylglycerol (DAG) and $\mathrm{IP}_{3}$, which in turn induces calcium release from the endoplasmic reticulum. Because the $\mathrm{IP}_{3}$ receptor blocker, 2-ABP, did not block the kisspeptin effect when applied intracellularly, we examined the effects of DAG. It is well recognized that TRPC3, TRPC6, and TRPC7 when expressed in a heterologous system can be directly activated by 1-oleoyl, 2-acetyl sn-glycerol (OAG), a permeable analog of DAG (Hofmann et al., 1999; Okada et al., 1999). However, if these subunits are combined with TRPC1 and TRPC4 or TRPC5, they should at best be weakly activated by OAG (Strübing et al., 2003). Indeed, we found that the OAG $(100 \mu \mathrm{M})$ activated a small inward current $(4.7 \pm 2.1 \mathrm{pA} ; n=7)$ in $\mathrm{GnRH}$ neurons (Fig. 9), which was $\sim 25.8 \%$ of the kisspeptin-activated currents $(18.2 \pm 1.7$ $\mathrm{pA} ; n=29$ ). This indicates that DAG is not the final messenger through which kisspeptin induces an inward current in GnRH neurons. It also indicates that heteromers within TRPC1, TRPC4, and TRPC5 subfamily or between the TRPC1, TRPC4, and TRPC5 subfamily and TRPC3, TRPC6, and TRPC7 subfamily might be formed and activated in GnRH neurons, which is consistent with the fact that the kisspeptinevoked currents are strongly inhibited by both 2-APB and FFA, but not potentiated by $\mathrm{La}^{3+}$ (Tozzi et al., 2003; Trebak et al., 2003; Zagranichnaya et al., 2005).

\section{Discussion}

We have shown for the first time that kisspeptin-10 potently depolarizes hypothalamic GnRH neurons through a combination of inhibiting an inwardly rectifying potassium conductance and activating a nonselective cationic (TRPC) conductance. We have deduced this based on several lines of evidence. First, extracellular barium, which blocks inwardly rectifying potassium channels, eliminated the ${E_{\mathrm{K}}}^{+}$-dependent reversal properties of the kisspeptininduced current. Second, the current-voltage relationship for the kisspeptin-induced current exhibited negative slope conductance, outward rectification, and a reversal around $0 \mathrm{mV}$ analogous to TRPC heteromeric channels expressed in HEK cells (Clapham, 2003). Third, the kisspeptin current was significantly attenuated by the TRPC channel blocker 2-APB, FFA, and to a lesser extent by the imadazole SKF96365 (Clapham et al., 2005). Fourth, the kisspeptin-induced inward current was essentially abolished in low extracellular $\mathrm{Na}^{+}$. And last but not least, we found that individual GnRH neurons express multiple TRPC channel transcripts. Therefore, the cumulative evidence supports the conclusion that kisspeptin excites GnRH neurons predominantly through the activation of nonselective cationic (TRPC) channels but also the inhibition of Kir channels.

Likely candidates for nonselective cationic channels in $\mathrm{GnRH}$ neurons include the TRPC channel family. The mammalian TRPC channel family consists of seven members, TRPC1TRPC7, that appear to function as receptor-operated channels, analogous to the transient receptor potential (TRP) channels involved in Drosophilia phototransduction (Clapham, 2003). With the exception of TRPC2, these channels are widely distributed in the mammalian brain (Venkatachalam and Montell, 2007). The TRP channels are made of subunits with six membrane-spanning domains that coassemble as tetrameric complexes similar to what has been described for $\mathrm{K}^{+}$channels (Clapham et al., 2001, 2005). However, TRPC channels appear to coassemble as heteromeric 
channels consisting of the TRPC1, TRPC4, and TRPC5 subfamily (Strübing et al., 2001; Plant and Schaefer, 2003) as well as TRPC3, TRPC6, and TRPC7 subfamily (Trebak et al., 2003; Berg et al., 2007). Indeed, based on the scRT-PCR, we found that all of the transcripts were expressed in GnRH neurons with exception of TRPC2, which is not functionally expressed in the mammalian brain (Clapham, 2003). Interestingly, TRPC4 and TRPC5 share 73\% homology, and TRPC3, TRPC6, and TRPC7 share $\sim 75 \%$ homology (Clapham, 2003). However, the functional distinction between these channel subtypes in CNS neurons has been problematic because of a lack of selective pharmacological reagents (Clapham et al., 2005). In our experiments with $\mathrm{K}^{+}$channel blockers on board, the current-voltage relationship for the kisspeptin-induced current resembled the current-voltage relationship of heteromeric complexes of TRPC1 plus TRPC4 or TRPC1 plus TRPC5 subunits expressed in HEK cells with the characteristic negative slope conductance and pronounced outward rectification (Strübing et al., 2001; Clapham, 2003). Similar current-voltage relationships have been obtained for the mGluR1- and CCK2-induced currents in basolateral amygdala neurons, and these neurons have been found to express the same compliment of TRPC channels as GnRH neurons (Faber et al., 2006; Meis et al., 2007).

The mammalian TRPC channels can be activated by G-protein-coupled receptors and receptor tyrosine kinases (for review, see Clapham, 2003; Ambudkar and Ong, 2007). In fact, in the CNS, TRPC channels are probably one of the major targets for mGluR1 signaling (Tozzi et al., 2003; Bengtson et al., 2004; Faber et al., 2006; Berg et al., 2007). Interestingly, in substantia nigra dopamine neurons, TRPC1 and TRPC5 are highly expressed and the mGluR1 agonist dihydroxyphenylglycine-induced current yields an "S" shape current-voltage plot (Tozzi et al., 2003). In addition, recent studies have shown that the peptide cholecystokinin via its receptor (CCK2) can also activate what appears to be TRPC1, TRPC4, and TRPC5 channels in amygdala neurons (Meis et al., 2007). Both the mGluR1 and CCK2 receptors are Gq-coupled to PLC activation, which leads to hydrolysis of $\mathrm{PIP}_{2}$ to $\mathrm{DAG}$ and $\mathrm{IP}_{3}$. In a heterologous cell expression system (i.e., Chinese hamster ovary K1 cells expressing GPR54 receptors), kisspeptin increases $\mathrm{IP}_{3}$ formation, calcium mobilization, arachidonic acid release, and MAP kinase phosphorylation (Kotani et al., 2001). Our data showed that the PLC inhibitor U73122 inhibited the kisspeptin effect. Therefore, it appears that GPR54 is Gq-coupled in GnRH neurons and can signal downstream to activate TRPC channels. Classically, the TRPC3, TRPC6, and TRPC7 subfamily is DAG sensitive (Clapham, 2003; Clapham et al., 2005; Ambudkar and Ong, 2007). Although TRPC3 and TRPC7 and to a lesser extend TRPC6 transcripts are expressed in GnRH neurons, the surrogate DAG signaling molecule OAG only had a small effect to activate an inward current $(\sim 25 \%$ of the kisspeptin-induced current) in GnRH neurons. In addition,
B

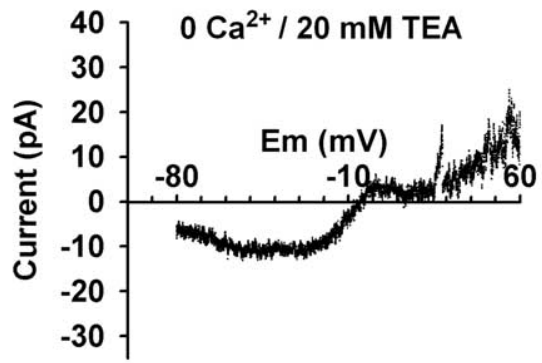

D

Calcium blocker + $0.3 \mathrm{mM} \mathrm{Ba}^{2+}$

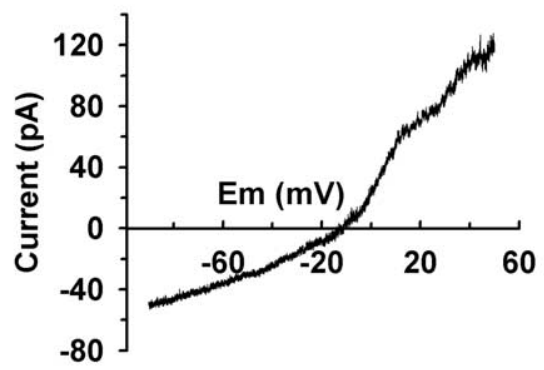

Figure 5. The $I-V$ relationships of the kisspeptin-activated nonselective cationic currents resemble TRPC channels. $\boldsymbol{A}-\boldsymbol{D}$, not affect the $I-V$ relationship of the kisspeptin-activated current but reduced the amplitude. $C$, In the presence of $0.3 \mathrm{~mm} \mathrm{Ba}{ }^{2+}$ slope at voltage more negative than $-10 \mathrm{mV}$. D, In the other $25 \%$ of the cells, the kisspeptin-activated currents reversed around $-10 \mathrm{mV}$ and the I-V relationship showed a doubly rectifying profile but with a positive slope conductance.

$\mathrm{La}^{3+}$ at a $100 \mu \mathrm{M}$ concentration, which should have potentiated TRPC4 and TRPC5 and blocked TRPC3, TRPC6, and TRPC7 (Clapham et al., 2005), essentially had no effect on the kisspeptininduced current. The lack of an effect may be attributable to the fact that an ensemble of these channel subunits exists in $\mathrm{GnRH}$ neurons. Indeed, 2-APB $(100 \mu \mathrm{M})$, which is a potent blocker of TRPC3, TRPC4, TRPC5, and TRPC6 channels, and FFA, which is a potent blocker of TRPC3, TRPC5, and TRPC7, did inhibit the effects of kisspeptin in GnRH neurons. These blockers had a similar efficacy on the mGluR1 activation of TRPC channels in substantia nigra dopamine neurons (Tozzi et al., 2003) and basolateral amygdala (Faber et al., 2006), and on CCK2 activation of TRPC channels in amygdala neurons (Meis et al., 2007). Therefore, although all of the "brain" TRPC channels are expressed in GnRH neurons, the TRPC4 and TRPC5 appear to be key players in mediating the effects of kisspeptin in GnRH neurons based on the $I-V$ relationship and the pharmacology (Lee et al., 2003).

To date, kisspeptin-10 is the most potent and efficacious neuropeptide/neurotransmitter to modulate $\mathrm{GnRH}$ neuronal activity (Lagrange et al., 1995; Spergel et al., 1999; DeFazio and Moenter, 2002; Han et al., 2002; Kuehl-Kovarik et al., 2002; Herbison, 2006). In addition to activating TRPC channels, kisspeptin also attenuated a resting (barium and cesium sensitive) Kir current in GnRH neurons. This effect of kisspeptin in GnRH neurons, albeit small, maybe critical because Kir channels (e.g., $\mathrm{K}_{\text {ATP }}$ channels) are highly expressed in GnRH neurons and clamp the cells in a negative resting state of $-63 \mathrm{mV}$ (Lagrange et al., 1995; Zhang et al., 2007). Therefore, by inhibiting Kir channels along with the 
A

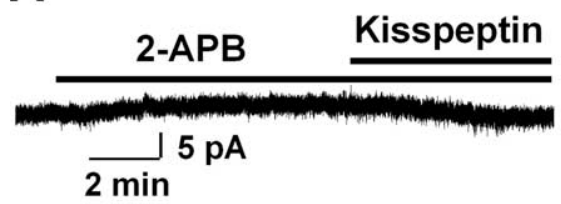

B

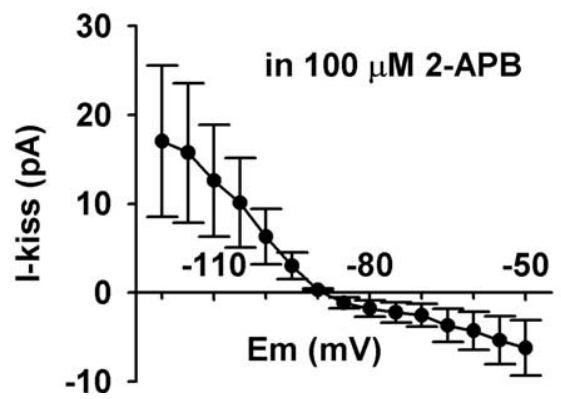

C

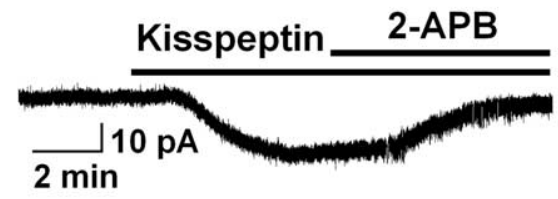

D

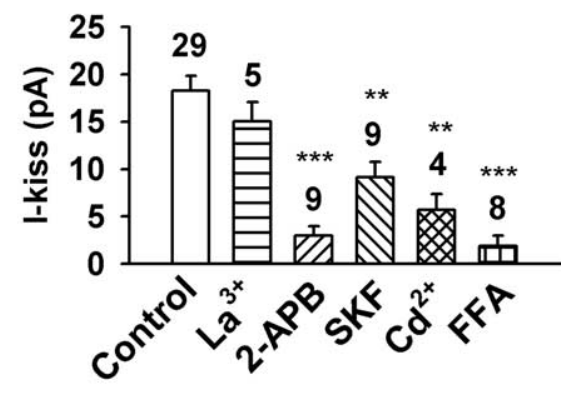

Figure 6. Effects of TRPC channel blockers on the kisspeptin-induced inward currents at $-60 \mathrm{mV}$. $\boldsymbol{A}$, A representative recording showing that 2-APB $(100 \mu \mathrm{M})$, which had very little effect on basal holding current, potently blocked the kisspeptin $(100 \mathrm{~nm})$-evoked inward current. $\boldsymbol{B}$, Mean $/-V$ relationship of the kisspeptin-sensitive current in the presence of 2-APB reversed at $-90 \mathrm{mV}(n=4)$, clearly indicating that a Kir channel was inhibited by kisspeptin. $C$, A representative recording showing that 2-APB $(100 \mu \mathrm{M})$ applied after kisspeptin also strongly blocked the kisspeptin-evoked inward current. $D$, Summary of the effect of

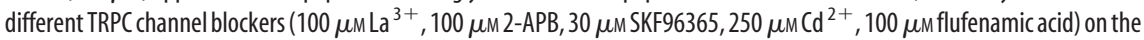
kisspeptin-induced inward currents at $-60 \mathrm{mV}$. Blockers were applied $5-7$ min before or after the application of kisspeptin (100 nм). The percentage inhibition for the different blockers was as follows: $17.4 \%$ for $100 \mu \mathrm{m} \mathrm{La}^{3+}, 83.6 \%$ for $100 \mu \mathrm{m} 2$ 2-APB, 50\% for $30 \mu \mathrm{m} \mathrm{SKF}, 68.7 \%$ for $250 \mu \mathrm{m} \mathrm{Cd}{ }^{2+}$, and $89.6 \%$ for $100 \mu \mathrm{m} \mathrm{FFA.}{ }^{* *} p<0.01$ and ${ }^{* * *} p<0.001$, significantly different from the control group. Cell numbers tested are indicated. Error bars indicate SEM.

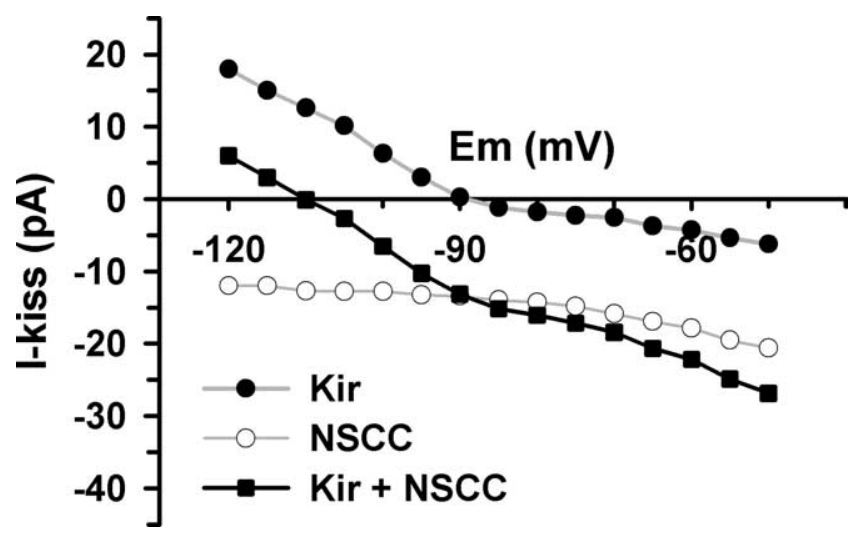

Figure 7. The sum of the kisspeptin-inhibited inwardly rectifying potassium current (Kir) and the kisspeptin-activated NSCC explains the apparent negative reversal potential of the kisspeptin-sensitive current in GnRH neurons. The Kir current is from Figure 6B, which is the mean kisspeptin-sensitive current in the presence of the TRPC channel blocker, 2-APB $(n=4)$. The NSCC current is the mean kisspeptin-activated current obtained with a $\mathrm{Cs}^{+}$-based internal solution $(n=6)$. The $I-V$ relationship of the summed currents (Kir $+\mathrm{NSCC}$ ) with the apparent negative reversal potential is similar to that in Figure 2D, which was obtained without pharmacological intervention.

pronounced activation of nonselective cationic (TRPC) channels, kisspeptin depolarizes the cells to threshold $(-45 \mathrm{mV})$ and induces sustained firing. This effect of kisspeptin would also be vital for inhibiting GPCR (G-protein-coupled receptor)activated ( $\mu$-opioid and GABA $_{B}$ ) GIRK (G-protein-gated inwardly rectifying potassium) currents, which are active in $\mathrm{GnRH}$ neurons (Lagrange et al., 1995). Therefore, the combination of inhibiting Kir channels and activating TRPC channels produces a pronounced excitation of GnRH neurons and sustained firing.

From a physiological perspective, the prolonged effects of kisspeptin in GnRH neurons are probably important for sexual maturation and adult reproduction (Han et al., 2005; Kauffman et al., 2007a). It is generally believed that kisspeptins are the endogenous ligands for the GPR54 receptor (Kotani et al., 2001). Indeed, it is known that mutations in GPR54 cause autosomal recessive idiopathic hypogonadotropic hypogonadism in humans (De Roux et al., 2003; Seminara et al., 2003), whereas deletion of GPR54 in mice causes defective sexual development and reproductive failure (Seminara et al., 2003). In addition, targeted deletion of the Kiss-1 gene in mice abrogates pubertal maturation and induces sterility and hypogonadotropic hypogonadism, essentially the same phenotype as GPR54 gene mutation (d'Anglemont de Tassigny et al., 2007). Interestingly, there are two anatomically distinct populations of kisspeptin neurons: one population is located in the arcuate nucleus and the other in the anteroventral periventricular nucleus. These are differentially regulated by estrogen (Smith et al., 2006), and it is the rostral group of neurons that are thought to be involved in the estrogen-mediated "positive" feedback (for review, see Kauffman et al., 2007b). It is also hypothesized that the caudal group of neurons are involved in estrogen-mediated "negative" feedback, which may be mediated via the differential release of kisspeptin/opioid peptides because this group of neurons also colocalizes dynorphin (Goodman et al., 2007). Indeed, we have described a robust $\mu$-opioid receptor-mediated inhibition of GnRH neurons (Lagrange et al., 1995), but a $\kappa$-opioidmediated effect has not been demonstrated.

In summary, we elucidated a cellular mechanism by which kisspeptin excites GnRH neurons that appears to involve both inhibition of Kir channels and activation of TRPC-like channels. Because it is evident that kisspeptins are essential for normal reproductive activity and play a key role in the onset of puberty (Han et al., 2005; Dungan et al., 2007; Kauffman et al., 2007b), it will be critical to elucidate how estrogen modulates kisspeptin signaling in GnRH neurons because this novel peptide appears to be a key neurotransmitter in generating the $\mathrm{GnRH}$ surge in mammals.

\section{References}

Ambudkar IS, Ong HL (2007) Organization and function of TRPC channelsomes. Pflügers Arch 455:187-200.

Bengtson CP, Tozzi A, Bernardi G, Mercuri NB (2004) Transient receptor potential-like channels mediate metabotropic glutamate receptor EPSCs in rat dopamine neurones. J Physiol (Lond) 555:323-330.

Berg AP, Sen N, Bayliss DA (2007) TrpC3/C7 and Slo2.1 are molecular targets for metabotropic glutamate receptor signaling in rat striatal cholinergic interneurons. J Neurosci 27:8845-8856.

Boulay G, Zhu X, Peyton M, Jiang M, Hurst R, Stefani E, Birnbaumer L (1997) Cloning and expression of a novel mammalian homolog of Drosophila transient receptor potential (TRP) involved in calcium entry secondary to activation of receptors coupled by the Gq class of G protein. J Biol Chem 272:29672-29680.

Bronson FH, Vom SF (1979) Control of the preovulatory release of luteinizing hormone by steroids in the mouse. Endocrinology 104:1247-1255. 
A

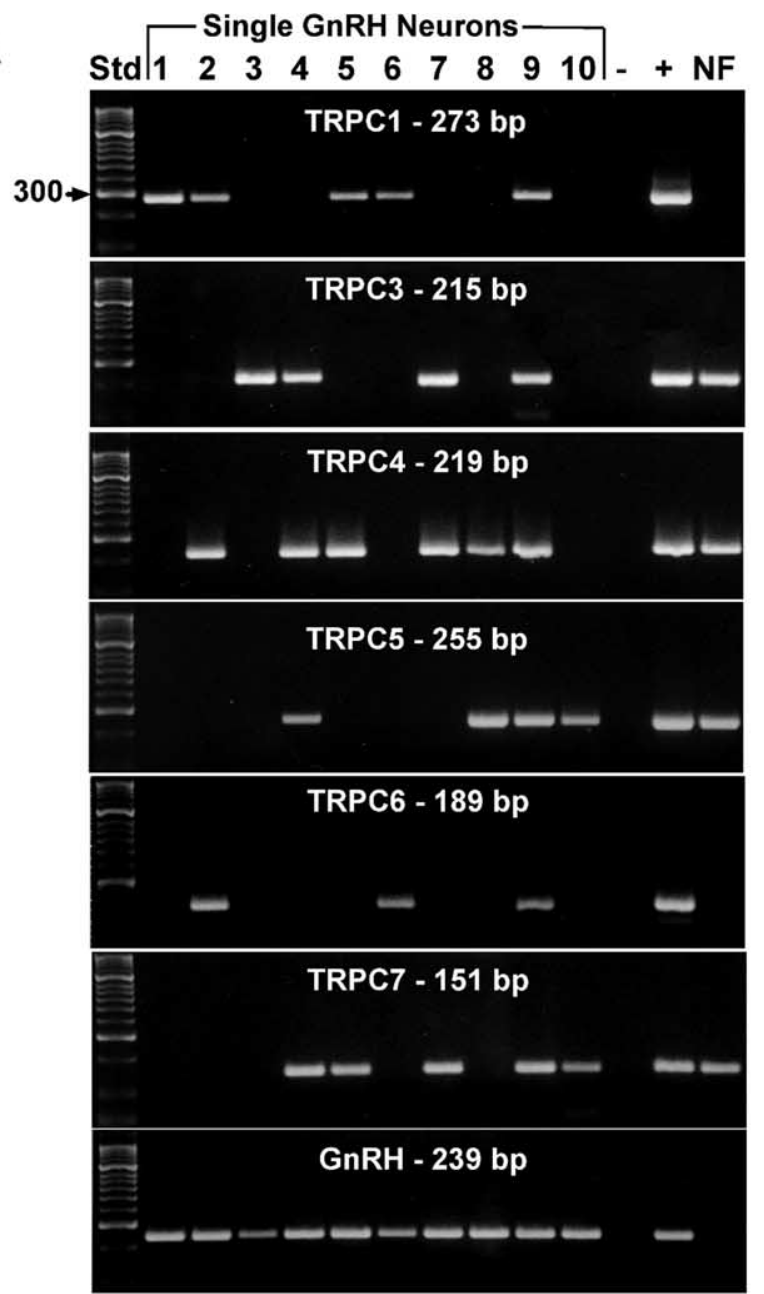

B

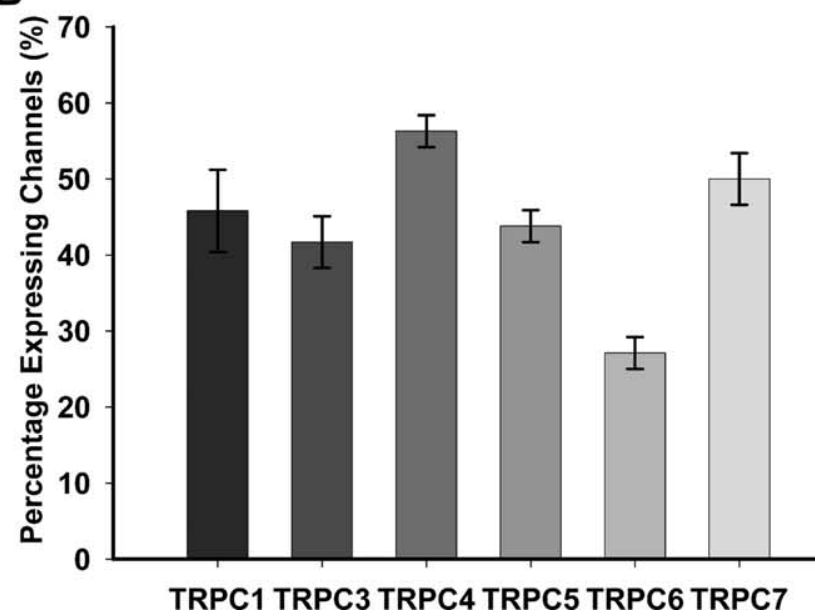

Figure 8. TRPC channel transcripts were expressed in $\mathrm{GnRH}$ neurons. $A$, A representative gel illustrating the expression of TRPC channel subunits in GnRH neurons harvested from intact female mice. The expected size of the PCR products is as follows (in base pairs): TRPC1, 273; TRPC3, 215; TRPC4, 219; TRPC5, 255; TRPC6, 189; TRPC7, 151; and GnRH, 239. Negative (-) control was amplified from a harvested cell without reverse transcriptase, and positive $(+)$ control was amplified using POA tissue. Nonfluorescent cells (NF) expressed TRPC3, TRPC4, TRPC5, and TRPC7 transcripts but did not express GnRH, TRPC1, or TRPC6 transcripts ( $n=9$ neurons). Other controls, including multiple aCSF samples from the dispersed cellular milieu collected during the cell harvesting, were negative after RT-PCR (data not shown). B, Quantitative analysis of the expression of TRPC1 and TRPC3-TRPC7 subunit mRNAs in GnRH neurons. Bar graphs represent the mean \pm SEM of percentage GnRH neurons expressing each TRPC subunit in four intact females.
A $100 \mu \mathrm{M}$ OAG

\section{$10 \mathrm{pA}$ \\ $1 \mathrm{~min}$}

B

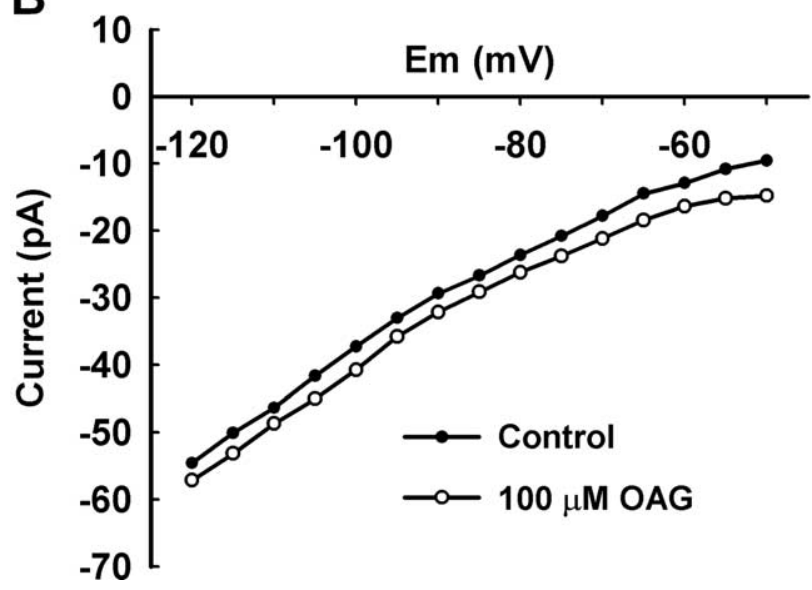

Figure 9. $O A G$ activated small inward currents in GnRH neurons. $A$, A representative recording shows that $100 \mu \mathrm{m}$ OAG activated a small inward current in a GnRH neuron. $\boldsymbol{B}$, The $I-V$ curve obtained from the recording in $\boldsymbol{A}$ showed that the OAG-induced inward current did not reverse around $E_{\mathrm{K}}{ }^{+}$, indicating the activation of a nonselective cationic current.

Carr DB, Surmeier DJ (2007) $M_{1}$ muscarinic receptor modulation of Kir2 channels enhances temporal summation of excitatory synaptic potentials in prefrontal cortex pyramidal neurons. J Neurophysiol 97:3432-3438.

Castellano JM, Navarro VM, Fernández-Fernández R, Nogueiras R, Tovar S, Roa J, Vazquez MJ, Vigo E, Casanueva FF, Aguilar E, Pinilla L, Dieguez C, Tena-Sempere M (2005) Changes in hypothalamic KiSS-1 system and restoration of pubertal activation of the repoductive axis by kisspeptin in undernutrition. Endocrinology 146:3917-3925.

Castellano JM, Navarro VM, Fernández-Fernández R, Castaño JP, Malagón MM, Aguilar E, Dieguez C, Magni P, Pinilla L, Tena-Sempere M (2006) Ontogeny and mechanisms of action for the stimulatory effect of kisspeptin on gonadotropin-releasing hormone system of the rat. Mol Cell Endocrinol 257-258:75-83.

Clapham DE (2003) TRP channels as cellular sensors. Nature 426:517-524. Clapham DE (2007) Snapshot: mammalian TRP channels. Cell 129:220.

Clapham DE, Runnels LW, Strübing C (2001) The TRP ion channel family. Nat Rev Neurosci 2:387-396.

Clapham DE, Julius D, Montell C, Schultz G (2005) International Union of Pharmacology. XLIX. Nomenclature and structure-function relationships of transient receptor potential channels. Pharmacol Rev $57: 427-450$.

Congar P, Leinekugel X, Ben-Ari Y, Crépel V (1997) A long-lasting calciumactivated nonselective cationic current is generated by synaptic stimulation or exogenous activation of group I metabotropic glutamate receptors in CA1 pyramidal neurons. J Neurosci 17:5366-5379.

d'Anglemont de Tassigny X, Fagg LA, Dixon JPC, Day K, Leitch HG, Hendrick AG, Zahn D, Franceschini I, Caraty A, Carlton MBL, Aparicio SAJR, Colledge WH (2007) Hypogonadotropic hypogonadism in mice lacking a functional KiSS 1 gene. Proc Natl Acad Sci USA 104:10714-10719.

DeFazio RA, Moenter SM (2002) Estradiol feedback alters potassium currents and firing properties of gonadotropin-releasing hormone neurons. Mol Endocrinol 16:2255-2265.

De Roux N, Genin E, Carel J-C, Matsuda F, Chaussain J-L, Milgrom E (2003) Hypogonadotropic hypogonadism due to loss of function of the KiSS 1-derived peptide receptor GPR54. Proc Natl Acad Sci USA 100:10972-10976.

Dungan HM, Gottsch ML, Zeng H, Gragerov A, Bergmann JE, Vassilatis DK, Clifton DK, Steiner RA (2007) The role of kisspeptin-GPR54 signaling 
in the tonic regulation and surge release of gonadotropin-releasing hormone/luteinizing hormone. J Neurosci 27:12088-12095.

Faber ESL, Sedlak P, Vidovic M, Sah P (2006) Synaptic activation of transient receptor potential channels by metabotropic glutamate receptors in the lateral amygdala. Neuroscience 137:781-794.

Gee DM, Flurkey K, Mobbs CV, Sinha YN, Finch CE (1984) The regulation of luteinizing hormone and prolactin in C57BL/6J mice: effects of estradiol implant size, duration of ovariectomy, and aging. Endocrinology 114:685-693.

Goodman RL, Lehman MN, Smith JT, Coolen LM, de Oliveira CVR, Jafarzadehshirazi MR, Pereira A, Iqbal J, Caraty A, Ciofi P, Clarke IJ (2007) Kisspeptin neurons in the arcuate nucleus of the ewe express both dynorphin A and neurokinin B. Endocrinology 148:5752-5760.

Gottsch ML, Cunningham MJ, Smith JT, Popa SM, Acohido BV, Crowley WF, Seminara S, Clifton DK, Steiner RA (2004) A role for kisspeptins in the regulation of gonadotropin secretion in the mouse. Endocrinology 145:4073-4077.

Gottsch ML, Clifton DK, Steiner RA (2006) Kisspepeptin-GPR54 signaling in the neuroendocrine reproductive axis. Mol Cell Endocrinol 254-255:91-96.

Haj-Dahmane S, Andrade R (1996) Muscarinic activation of a voltagedependent cation nonselective current in rat association cortex. J Neurosci 16:3848-3861.

Halaszovich CR, Zitt C, Jüngling E, Lückhoff A (2000) Inhibition of TRP3 channels by lanthanides. Block from the cytosolic side of the plasma membrane. J Biol Chem 275:37423-37428.

Han SK, Abraham IM, Herbison AE (2002) Effect of GABA on GnRH neurons switches from depolarization to hyperpolarization at puberty in the female mouse. Endocrinology 143:1459-1466.

Han SK, Gottsch ML, Lee KJ, Popa SM, Smith JT, Jakawich SK, Clifton DK, Steiner RA, Herbison AE (2005) Activation of gonadotropin-releasing hormone neurons by kisspeptin as a neuroendocrine switch for the onset of puberty. J Neurosci 25:11349-11356.

Herbison AE (2006) Physiology of the gonadotropin-releasing hormone neuronal network. In: Knobil and Neill's physiology of reproduction, Ed 3 (Neill JD, ed), pp 1415-1482. Boston: Elsevier.

Hofmann T, Obukhov AG, Schaefer M, Harteneck C, Gudermann T, Schultz G (1999) Direct activation of human TRPC6 and TRPC3 channels by diacylglycerol. Nature 397:259-263.

Hofmann T, Schaefer M, Schultz G, Gudermann T (2000) Cloning, expression and subcellular localization of two novel splice variants of mouse transient receptor potential channel 2. Biochem J 351:115-122.

Ibrahim N, Bosch MA, Smart JL, Qiu J, Rubinstein M, Rønnekleiv OK, Low MJ, Kelly MJ (2003) Hypothalamic proopiomelanocortin neurons are glucose-responsive and express K-ATP channels. Endocrinology 144:1331-1340.

Inoue R, Okada T, Onoue H, Hara Y, Shimizu S, Naitoh S, Ito Y, Mori Y (2001) The transient receptor potential protein homologue TRP6 is the essential component of vascular alpha(1)-adrenoceptor-activated $\mathrm{Ca}^{2+}$. permeable cation channel. Circ Res 88:325-332.

Irwig MS, Fraley GS, Smith JT, Acohido BV, Popa SM, Cunningham MJ, Gottsch ML, Clifton DK, Steiner RA (2004) Kisspeptin activation of gonadotropin releasing hormone neurons and regulation of KiSS-1 mRNA in the male rat. Neuroendocrinology 80:264-272.

Jung S, Muhle A, Schaefer M, Strotmann R, Schultz G, Plant TD (2003) Lanthanides potentiate TRPC 5 currents by an action at extracellular sites close to the pore mouth. J Biol Chem 278:3562-3571.

Kamouchi M, Philipp S, Flockerzi V, Wissenbach U, Mamin A, Raeymaekers L, Eggermont J, Droogmans G, Nilius B (1999) Properties of heterologously expressed hTRP 3 channels in bovine pulmonary artery endothelial cells. J Physiol (Lond) 518:345-358.

Kauffman AS, Park JH, McPhie-Lalmansingh AA, Gottsch ML, Bodo C, Hohmann JG, Pavlova MN, Rohde AD, Clifton DK, Steiner RA, Rissman EF (2007a) The kisspeptin receptor GPR54 is required for sexual differentiation of the brain and behavior. J Neurosci 27:8826-8835.

Kauffman AS, Clifton DK, Steiner RA (2007b) Emerging ideas about kisspeptin-GPR54 signaling in the neuroendocrine regulation of reproduction. Trends Neurosci 30:504-511.

Kotani M, Detheux M, Vandenbogaerde A, Communi D, Vanderwinden JM, Le Poul E, Brezillon S, Tyldesley R, Suarez-Huerta N, Vandeput F, Blanpain C, Schiffmann SN, Vassart G, Parmentier M (2001) The metastasis suppressor gene KiSS-1 encodes kisspeptins, the natural ligands of the orphan G protein-coupled receptor GPR54. J Biol Chem 276:34631-34636.

Kuehl-Kovarik MC, Pouliot WA, Halterman GL, Handa RJ, Dudek FE, Partin KM (2002) Episodic bursting activity and response to excitatory amino acids in acutely dissociated gonadotropin-releasing hormone neurons genetically targeted with green fluorescent protein. J Neurosci 22:2313-2322.

Kuohung W, Kaiser UB (2006) GPR54 and KiSS-1: role in the regulation of puberty and reproduction. Rev Endocr Metab Disord 7:257-263.

Lacey MG, Mercuri NB, North RA (1988) On the potassium conductance increase activated by $\mathrm{GABA}_{\mathrm{B}}$ and dopamine $\mathrm{D}_{2}$ receptors in rat substantia nigra neurones. J Physiol (Lond) 401:437-453.

Lagrange AH, Rønnekleiv OK, Kelly MJ (1995) Estradiol-17 $\beta$ and $\mu$-opioid peptides rapidly hyperpolarize GnRH neurons: a cellular mechanism of negative feedback? Endocrinology 136:2341-2344.

Lee YM, Kim BJ, Kim HJ, Yang DK, Zhu MH, Lee KP, So I, Kim KW (2003) TRPC5 as a candidate for the nonselective cation channel activated by muscarinic stimulation in murine stomach. Am J Physiol 284:G604-G616.

Lei WB, Talley EM, Bayliss DA (2001) Receptor-mediated inhibition of G protein-coupled inwardly rectifying potassium channels involves $\mathrm{Ga}_{\mathrm{q}}$ family subunits, phospholipase $\mathrm{C}$, and a readily diffusible messenger. J Biol Chem 276:16720-16730.

Liman ER, Corey DP, Dulac C (1999) TRP2: a candidate transduction channel for mammalian pheromone sensory signaling. Proc Natl Acad Sci USA 96:5791-5796.

Meis S, Munsch T, Sosulina L, Pape H-C (2007) Postsynaptic mechanisms underlying responsiveness of amygdloid neurons to cholecystrokinin are mediated by a transient receptor potential-like current. Mol Cell Neurosci 35:356-367.

Merritt JE, Armstrong WP, Benham CD, Hallam TJ, Jacob R, Jaxa-Chamiec A, Leigh BK, McCarthy SA, Moores KE, Rink TJ (1990) SK\&F 96365, a novel inhibitor of receptor-mediated calcium entry. Biochem J 271:515-522.

Messager S, Chatzidaki EE, Ma D, Hendrick AG, Zahn D, Dixon J, Thresher RR, Malinge I, Lomet D, Carlton MBL, Colledge WH, Caraty A, Aparicio SA (2005) Kisspeptin directly stimulates gonadotropin-releasing hormone release via G protein-coupled receptor 54. Proc Natl Acad Sci USA 102:1761-1766.

Muir AI, Chamberlain L, Elshourbagy NA, Michalovich D, Moore DJ, Calamari A, Szekeres PG, Sarau HM, Chambers JK, Murdock P, Steplewski K, Shabon U, Miller JE, Middleton SE, Darker JG, Larminie CG, Wilson S, Bergsma DJ, Emson P, Faull R, et al. (2001) AXOR12, a novel human G protein-coupled receptor, activated by the peptide KiSS-1. J Biol Chem 276:28969-28975.

Navarro VM, Castellano JM, Fernández-Fernández R, Barreiro ML, Roa J, Sanchez-Criado JE, Aguilar E, Dieguez C, Pinilla L, Tena-Sempere M (2004) Developmental and hormonally regulated messenger ribonucleic acid expression of KiSS-1 and its putative receptor, GPR54, in rat hypothalamus and potent luteinizing hormone-releasing acitivity of KiSS-1 peptide. Endocrinology 145:4565-4574.

Ohtaki T, Shintani Y, Honda S, Matsumoto H, Hori A, Kanehashi K, Terao Y, Kumano S, Takatsu Y, Masuda Y, Ishibashi Y, Watanabe T, Asada M, Yamada T, Suenaga M, Kitada C, Usuki S, Kurokawa T, Onda H, Nishimura O, et al. (2001) Metastasis suppressor gene KiSS-1 encodes peptide ligand of a G-protein-coupled receptor. Nature 411:613-617.

Okada T, Inoue R, Yamazaki K, Maeda A, Kurosaki T, Yamakuni T, Tanaka I, Shimizu S, Ikenaka K, Imoto K, Mori Y (1999) Molecular and functional characterization of a novel mouse transient receptor potential protein homologue TRP7. $\mathrm{Ca}^{2+}$-permeable cation channel that is constitutively activated and enhanced by stimulation of $\mathrm{G}$ protein-coupled receptor. J Biol Chem 274:27359-27370.

Owen JM, Quinn CC, Leach R, Findlay JBC, Boyett MR (1999) Effect of extracellular cations on the inward rectifying $\mathrm{K}^{+}$channels Kir2.1 and Kir3.1/Kir3.4. Exp Physiol 84:471-488.

Pielecka-Fortuna J, Chu Z, Moenter SM (2008) Kisspeptin acts directly and indirectly to increase GnRH neuron activity and its effects are modulated by estradiol. Endocrinology 149:1979-1986.

Plant TD, Schaefer M (2003) TRPC4 and TRPC5: receptor-operated $\mathrm{Ca}^{2+}$ permeable nonselective cation channels. Cell Calcium 33:441-450.

Plant TM (2006) The role of KiSS-1 in the regulation of puberty in higher primates. Eur J Endocrinol 155:S11-S16. 
Qiu J, Bosch MA, Tobias SC, Grandy DK, Scanlan TS, Rønnekleiv OK, Kelly MJ (2003) Rapid signaling of estrogen in hypothalamic neurons involves a novel $\mathrm{G}$ protein-coupled estrogen receptor that activates protein kinase C. J Neurosci 23:9529-9540.

Quaynor S, Hu L, Leung PK, Feng H, Mores N, Krsmanovic LZ, Catt KJ (2007) Expression of a functional GPR54-kisspeptin autoregulatory system in hypothalamic GnRH neurons. Mol Endocrinol 21:3062-3070.

Riccio A, Mattei C, Kelsell RE, Medhurst AD, Calver AR, Randall AD, Davis JB, Benham CD, Pangalos MN (2002) Cloning and functional expression of human short TRP7, a candidate protein for store-operated $\mathrm{Ca}^{2+}$ influx. J Biol Chem 277:12302-12309.

Roa J, Vigo E, Castellano JM, Navarro VM, Fernández-Fernández R, Casanueva FF, Dieguez C, Aguilar E, Pinilla L, Tena-Sempere M (2006) Hypothalamic expression of Kiss-1 system and gonadotropin-releasing effects of kisspeptin in different reproductive states of the female rat. Endocrinology 147:2864-2878

Schaefer M, Plant TD, Obukhov AG, Hofmann T, Gudermann T, Schultz G (2000) Receptor-meidated regulation of the nonselective cation channels TRPC4 and TRPC5. J Biol Chem 275:17517-17526.

Seminara SB, Messager S, Chatzidaki EE, Thresher RR, Acierno JS, Shagoury JK, Bo-Abbas Y, Kuohung W, Schwinof KM, Hendrick AG, Zahn D, Dixon J, Kaiser UB, Slaugenhaupt SA, Gusella JF, O’Rahilly S, Carlton MB, Crowley WF, Aparicio SA, Colledge WH (2003) The GPR54 gene as a regulator of puberty. $\mathrm{N}$ Engl J Med 349:1614-1627.

Slugg RM, Rønnekleiv OK, Grandy DK, Kelly MJ (1999) Activation of an inwardly-rectifying $\mathrm{K}^{+}$conductance by orphanin $\mathrm{FQ}$ /nociceptin in vasopressin containing neurons. Neuroendocrinology 69:385-396.

Smith JT, Popa SM, Clifton DK, Hoffman GE, Steiner RA (2006) Kiss1 neurons in the forebrain as central processors for generating the preovulatory luteinizing hormone surge. J Neurosci 26:6687-6694.

Spergel DJ, Kruth U, Hanley DF, Sprengel R, Seeburg PH (1999) GABAand glutamate activated channels in green fluorescent protein-tagged gonadotropin-releasing hormone neurons in transgenic mice. J Neurosci 19:2037-2050.

Stafford LJ, Xia C, Ma W, Cai Y, Liu M (2002) Identification and characterization of mouse metastasis-suppressor KiSS1 and its G-protein-couple receptor. Cancer Res 62:5399-5404.

Strübing C, Krapivinsky G, Krapivinsky L, Clapham DE (2001) TRPC1 and TRPC5 form a novel cation channel in mammalian brain. Neuron 29:645-655.
Strübing C, Krapivinsky G, Krapivinsky L, Clapham DE (2003) Formation of novel TRPC channels by complex subunit interactions in embryonic brain. J Biol Chem 278:39014-39019.

Suter KJ, Song WJ, Sampson TL, Wuarin J-P, Saunders JT, Dudek FE, Moenter SM (2000) Genetic targeting of green fluorscent protein to gonadotropin-releasing hormone neurons: characterization of whole-cell electrophysiological properties and morphology. Endocrinology 141:412-419.

Tena-Sempere M (2006) Kiss-1 and reproduction: focus on its role in the metabolic regulation of fertility. Neuroendocrinology 83:275-281.

Tozzi A, Bengtson CP, Longone P, Carignani C, Fusco FR, Bernardi G, Mercuri NB (2003) Involvement of transient receptor potential-like channels in responses to mGLuR-I activation in midbrain dopamine neurons. Eur J Neurosci 18:2133-2145.

Trebak M, Vazquez G, Bird GS, Putney Jr JW (2003) The TRPC3/6/7 subfamily of cation channels. Cell Calcium 33:451-461.

van Rossum DB, Patterson RL, Ma HT, Gill DL (2000) $\mathrm{Ca}^{2+}$ entry mediated by store depletion, $S$-nitrosylation, and TRP3 channels. Comparison of coupling and function. J Biol Chem 275:28562-28568.

Velimirovic BM, Koyano K, Nakajima S, Nakajima Y (1995) Opposing mechanisms of regulation of a G-protein-coupled inward rectifier $\mathrm{K}^{+}$ channel in rat brain neurons. Proc Natl Acad Sci USA 92:1590-1594.

Venkatachalam K, Montell C (2007) TRP channels. Annu Rev Biochem 76:387-417.

Xu SZ, Zeng F, Boulay G, Grimm C, Harteneck C, Beech DJ (2005) Block of TRPC5 channels by 2 -aminoethoxydiphenyl borate: a differential, extracellular and voltage-dependent effect. Br J Pharmacol 145:405-414.

Zagranichnaya TK, Wu X, Villereal ML (2005) Endogenous TRPC1, TRPC3, and TRPC7 proteins combine to form native store-operated channels in HEK-293 cells. J Biol Chem 280:29559-29569.

Zhang C, Bosch MA, Levine JE, Rønnekleiv OK, Kelly MJ (2007) Gonadotropin-releasing hormone neurons express $\mathrm{K}_{\mathrm{ATP}}$ channels that are regulated by estrogen and responsive to glucose and metabolic inhibition. J Neurosci 27:10153-10164.

Zhu X, Jiang M, Birnbaumer L (1998) Receptor-activated $\mathrm{Ca}^{2+}$ influx via human Trp3 stably expressed in human embryonic kidney (HEK) 293 cells. Evidence for a non-capacitative $\mathrm{Ca}^{2+}$ entry. J Biol Chem 273:133142 . 